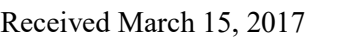

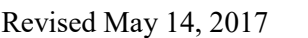

पणाणाण पाणाणाए

\title{
On Peace Capital: The Case of Academic Cultural Capital Inside the United Nations and its Universities $\square$
}

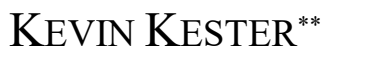

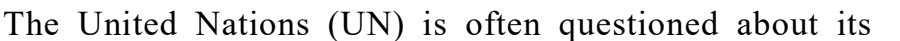

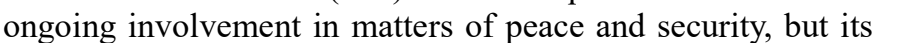

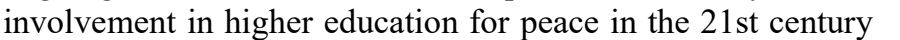

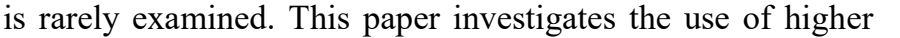

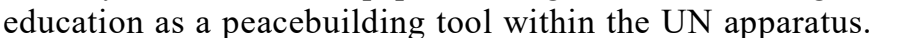

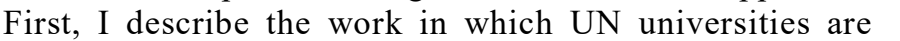

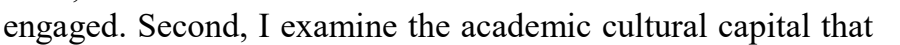

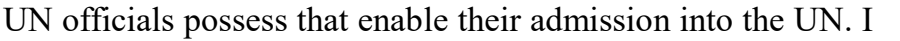

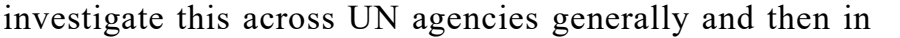

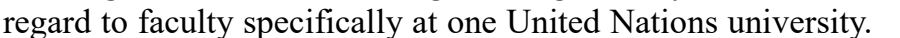

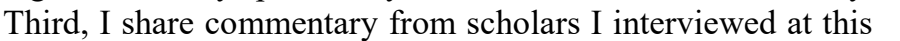

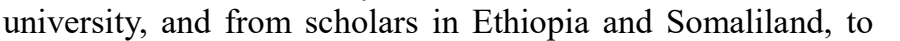

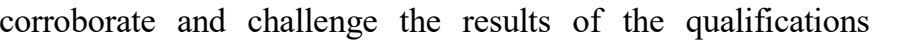

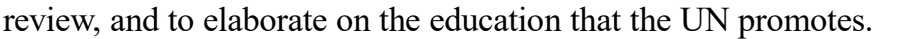

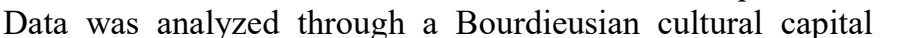

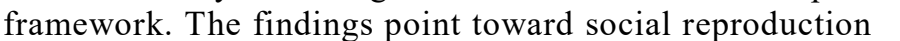

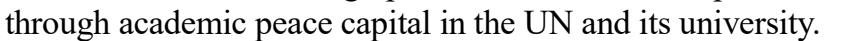

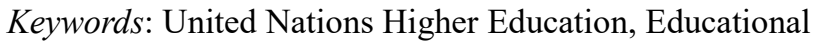

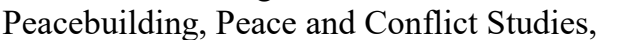

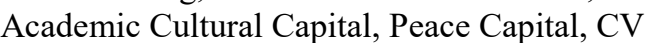
$\square \square\|ण\| \square$

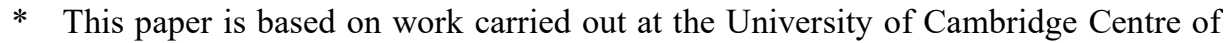

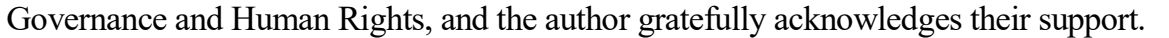

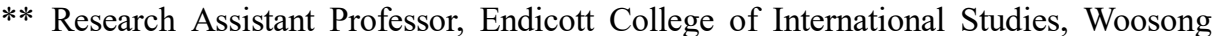

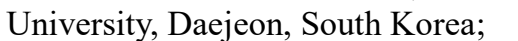

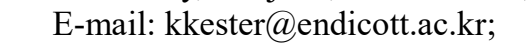

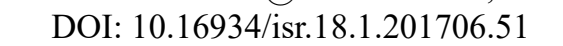




\section{SOCIOLOGY OF PEACE}

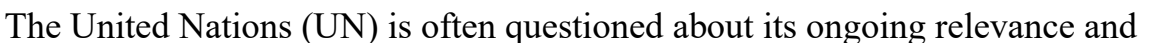
ए।

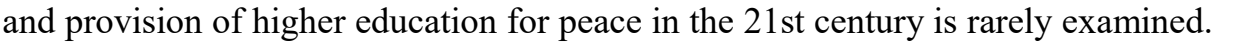

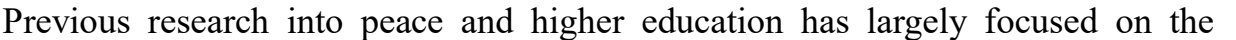

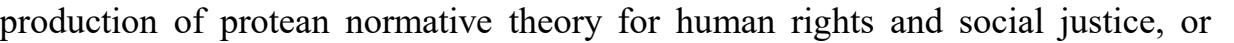

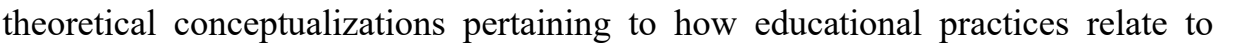

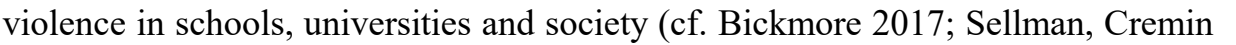

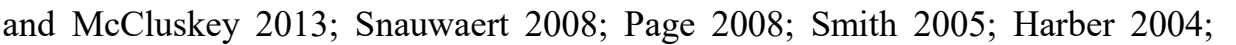

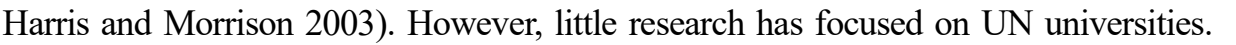

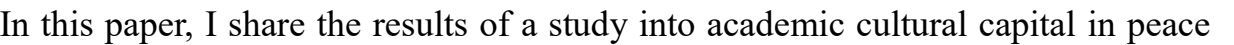

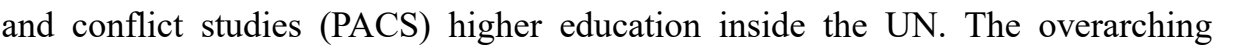

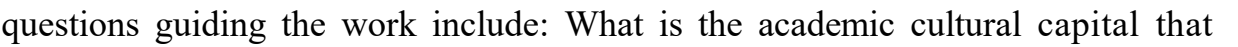

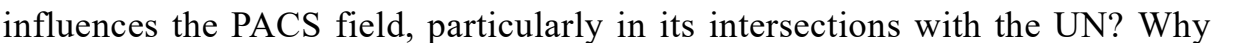

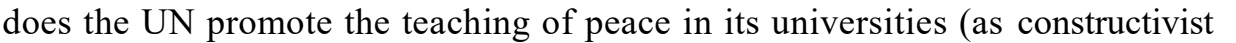

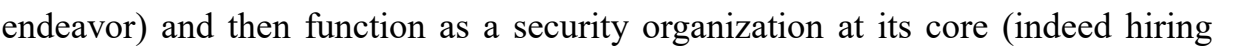

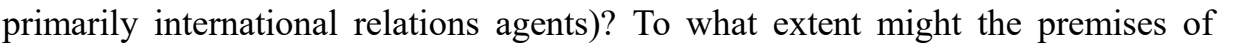

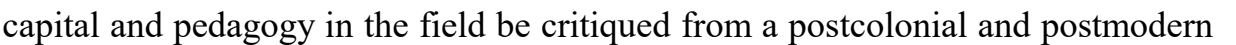
$\square\|\|\|\|\|\| \| \square$

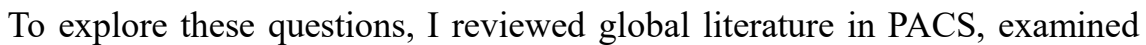

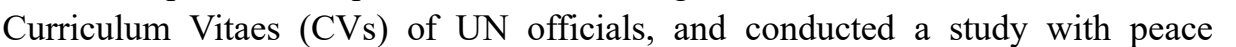

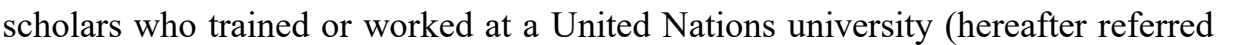

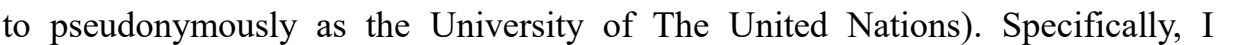

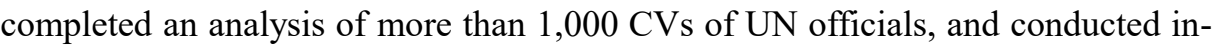

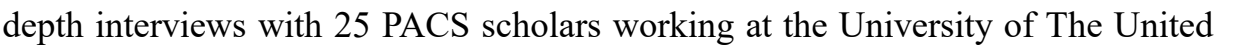

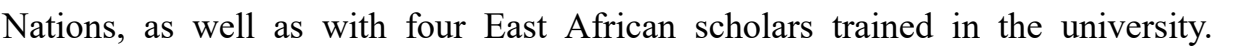
$\square \square$ ewhere I augmented this data with a review of the university's curriculum,

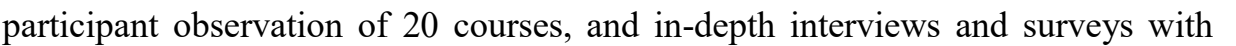

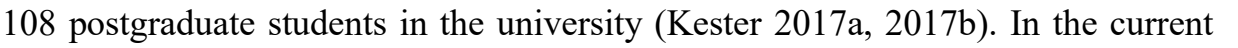

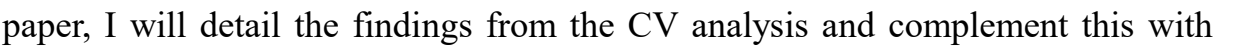

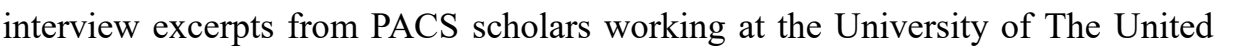

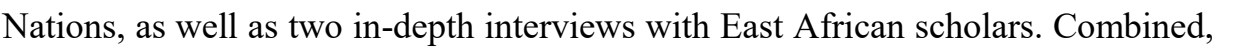

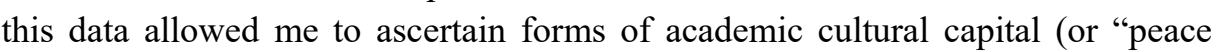
capital") that might have provided scholars with privileged access into a position

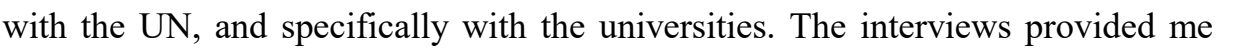

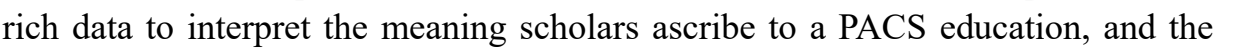

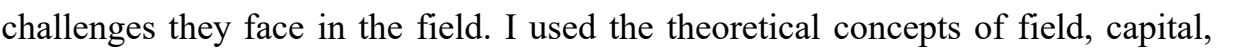

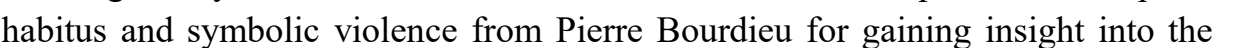

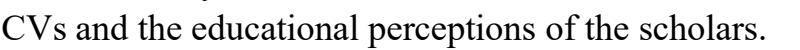

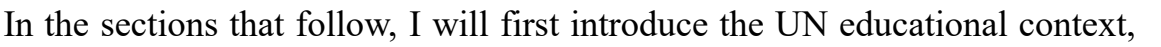


outline the conceptual "thinking tools" of Bourdieu, explain the methodology through which I collected data, and then apply Bourdieu's tools to an analysis of एवण

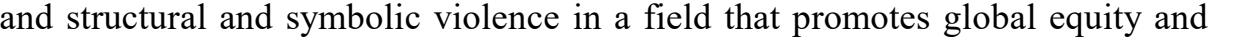

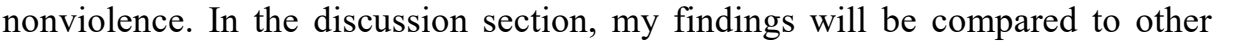

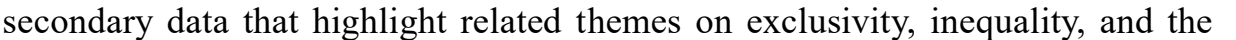

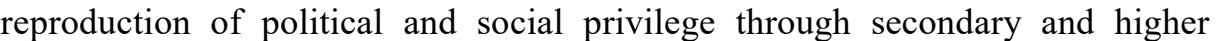
education (cf. O’Rourke, Hogan and Donnelly 2015; Howard and Gaztambide $\square$

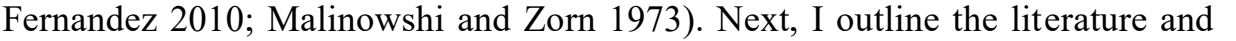

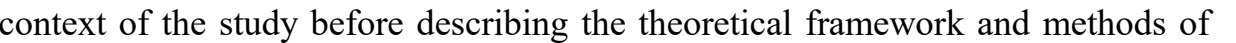
पाणाणाएण

\section{LITERATURE AND EDUCATIONAL CONTEXT}

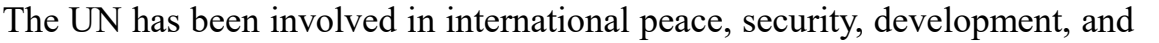

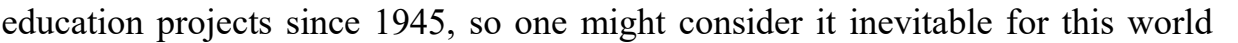

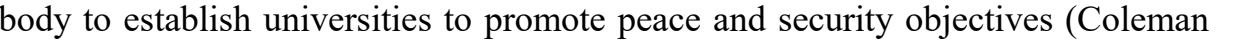

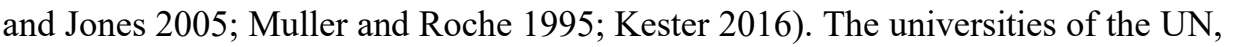

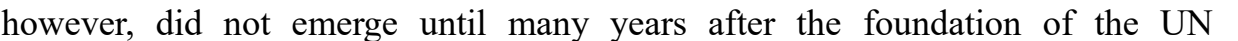

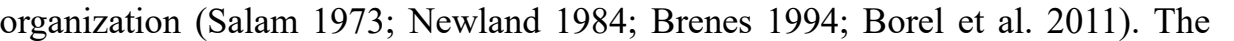

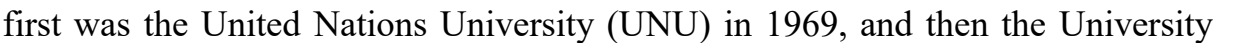
ए एव

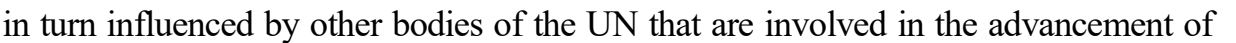

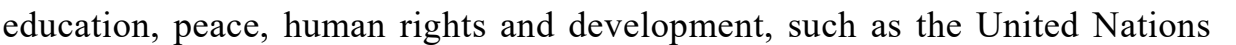

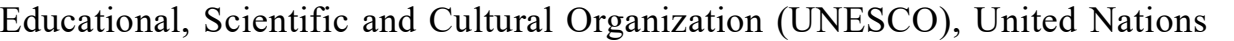

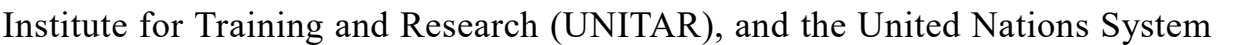

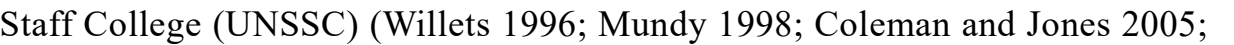

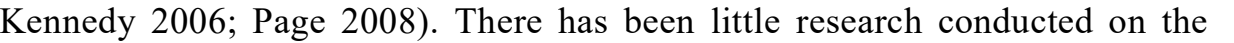

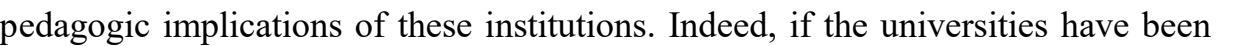

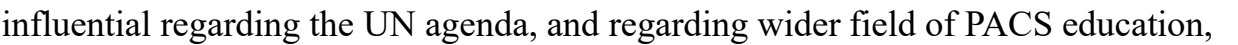

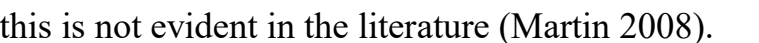

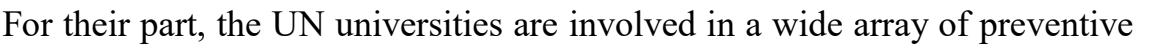

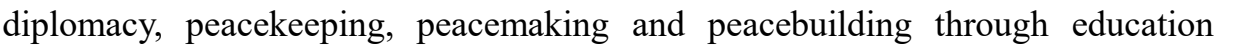

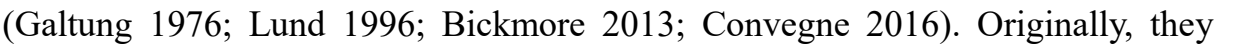

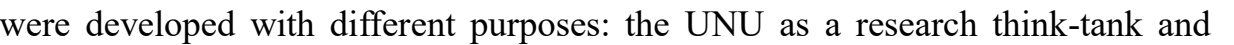

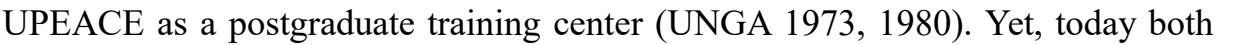

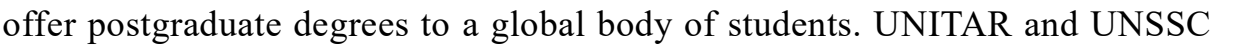

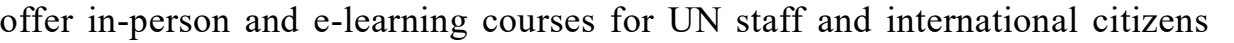

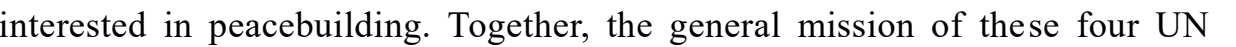

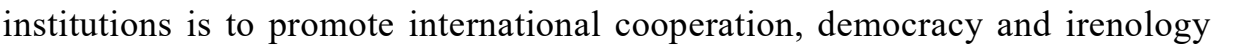

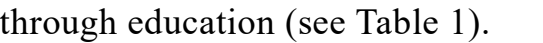




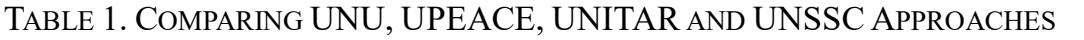

\begin{tabular}{|c|c|c|c|c|}
\hline & प्व० & 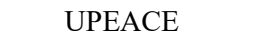 & पमापिए & 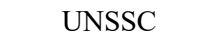 \\
\hline 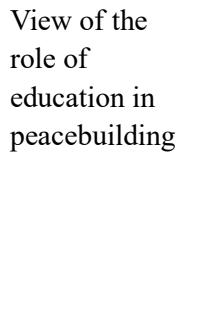 & 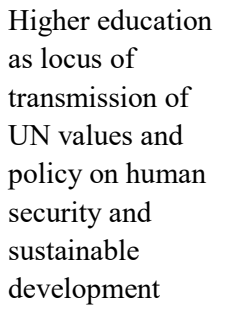 & 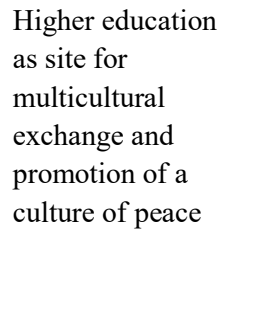 & 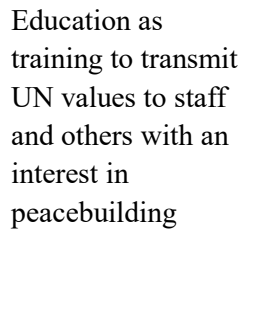 & 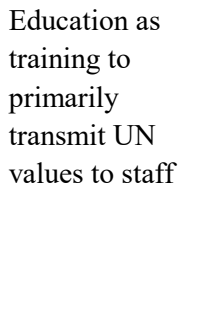 \\
\hline 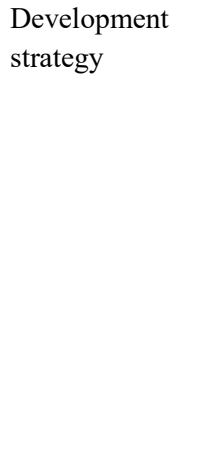 & 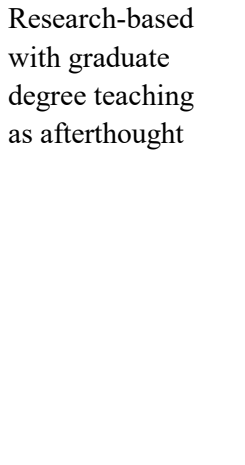 & 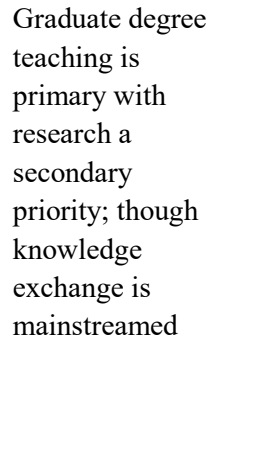 & 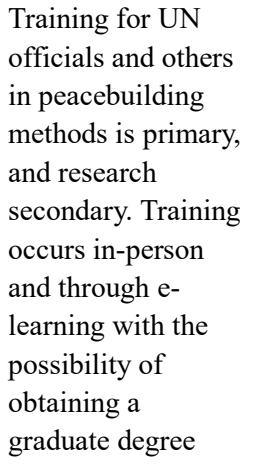 & 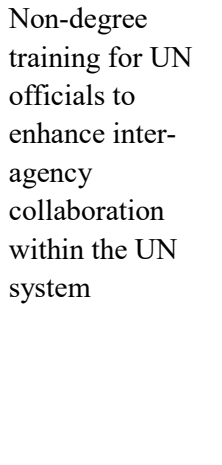 \\
\hline 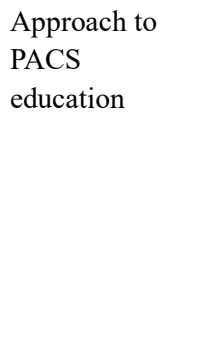 & 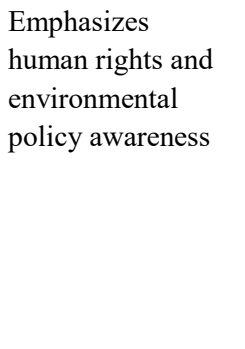 & 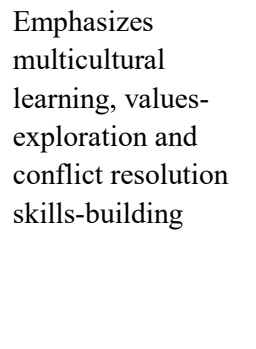 & 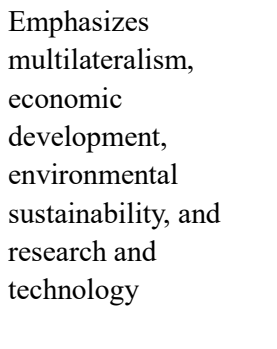 & 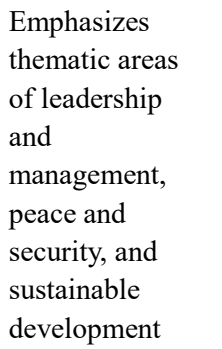 \\
\hline
\end{tabular}

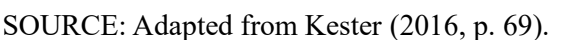

$\square$

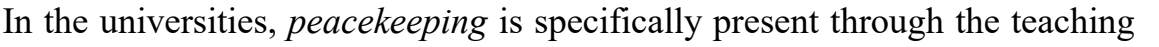

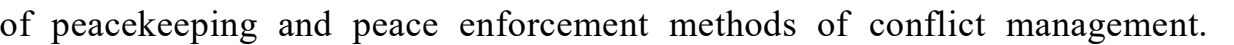

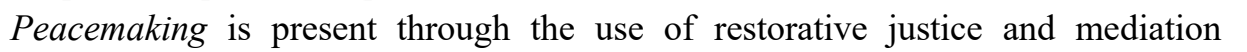

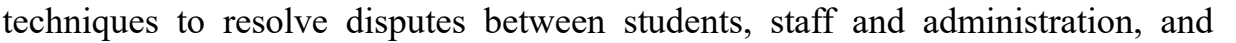

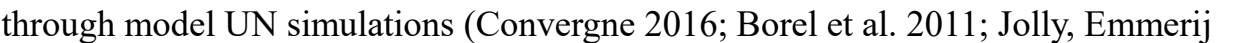

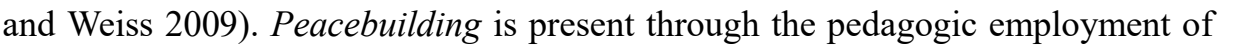

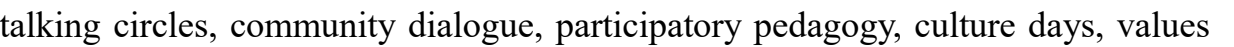

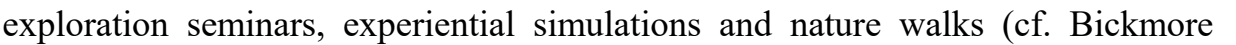

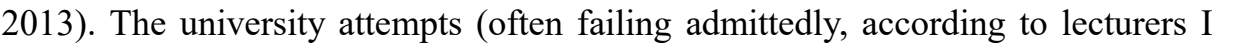

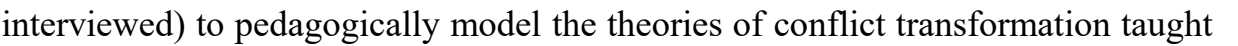

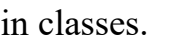




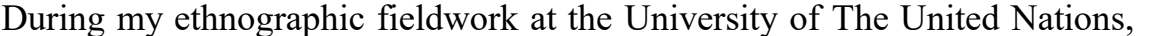

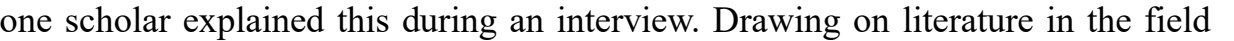

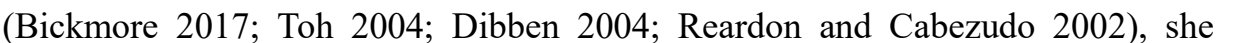

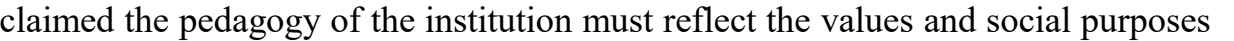

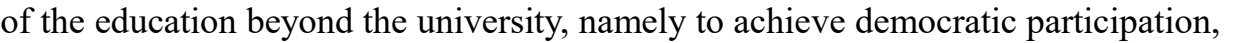

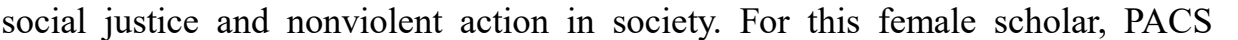

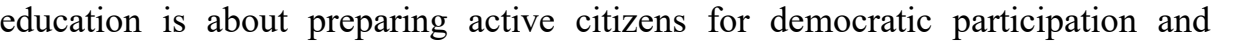

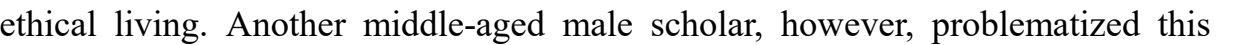

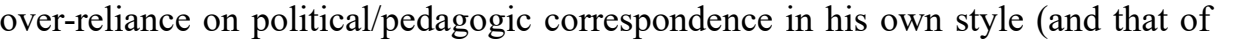

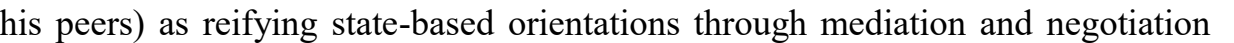

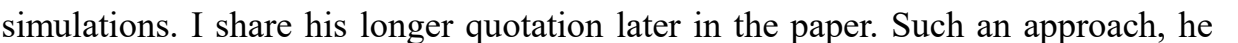

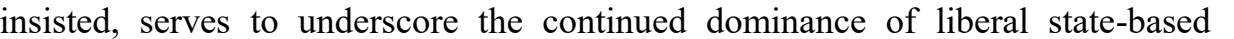

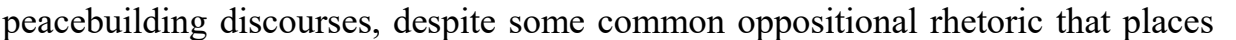
ए

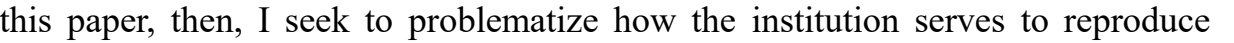

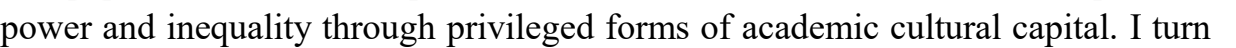

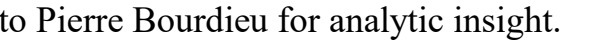

$\square$

\section{THEORETICAL FRAMEWORK}

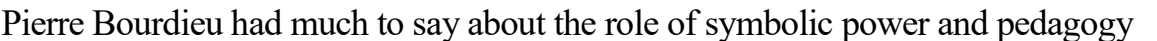

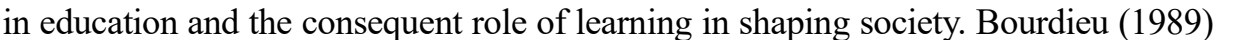
suggested, for example, that, "to change the world, one has to change the ways of

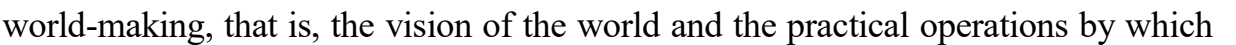

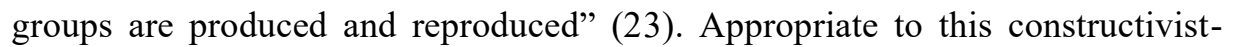

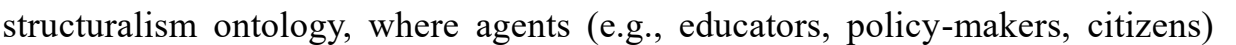

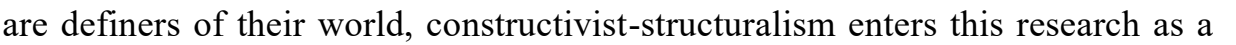

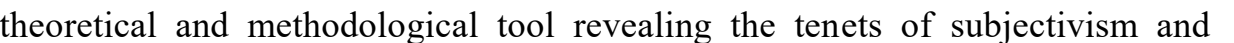
relational realist ontologies that permeate research into academics' perspectives

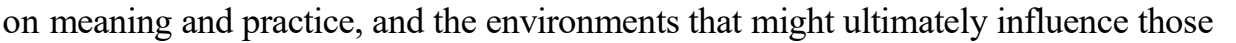

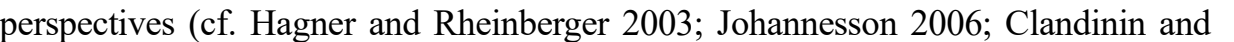

Connelly 1996). To do this, Bourdieu developed a number of "thinking tools" that

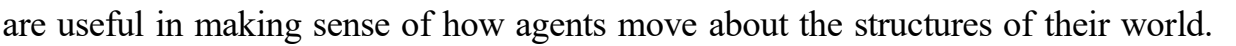

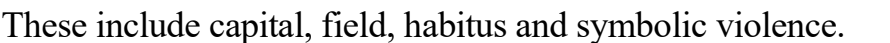

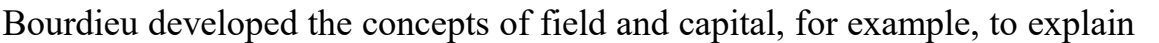

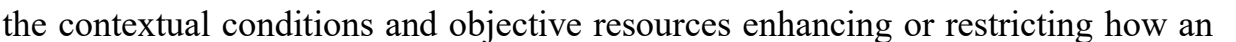
agent moves about and impacts her/his domain of practice. The field refers to "a

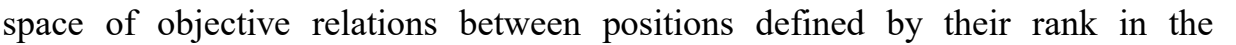
distribution of competing powers or species of capital" (Bourdieu and Wacquant

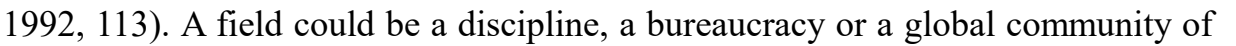

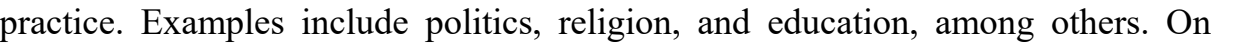




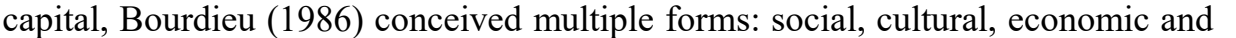

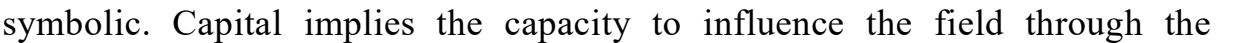

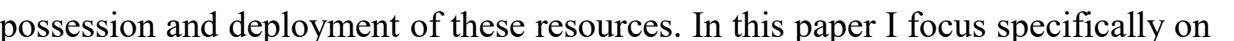

Bourdieu's cultural capital with occasional references to economic and social

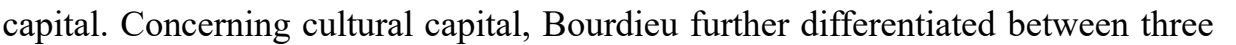

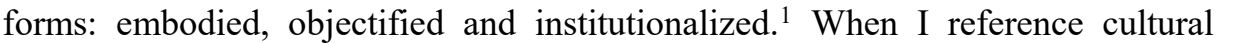
capital, I am primarily referring to Bourdieu's ideas on the institutionalized state

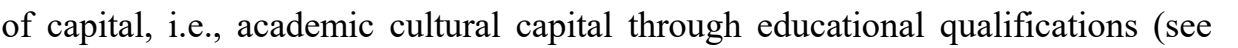

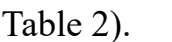

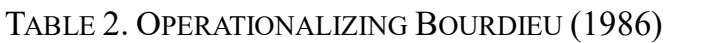

\begin{tabular}{|c|c|c|}
\hline प्पाएा & $\square \amalg ण \square$ & 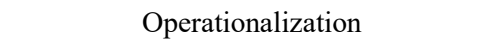 \\
\hline 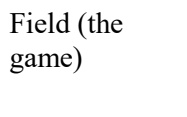 & 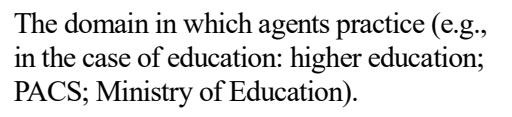 & 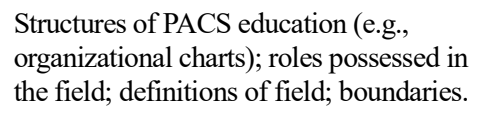 \\
\hline 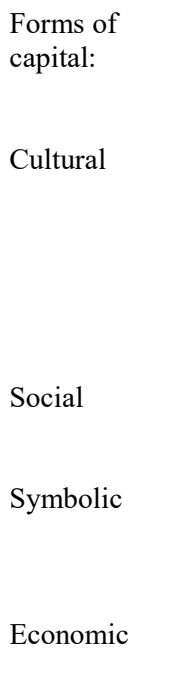 & 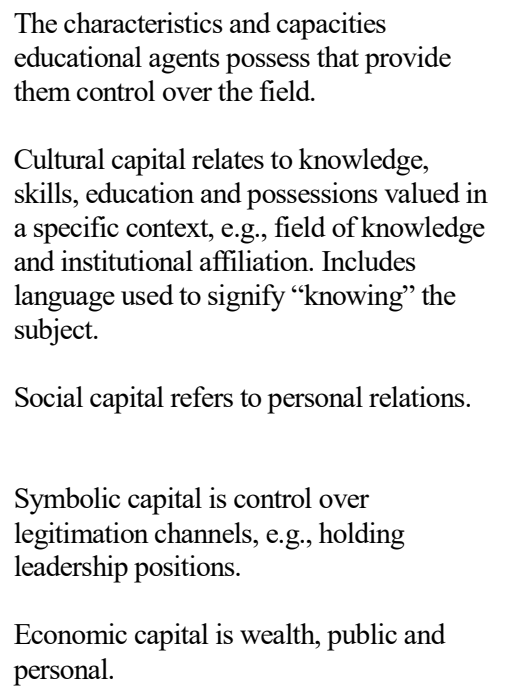 & 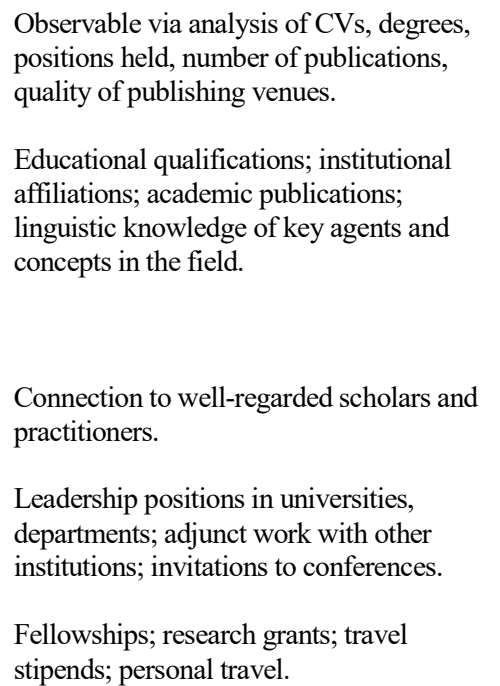 \\
\hline 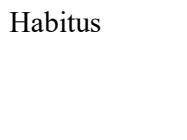 & 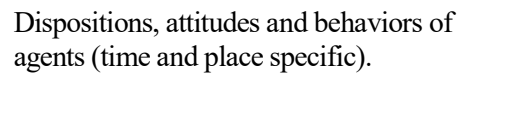 & 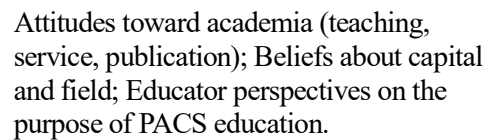 \\
\hline
\end{tabular}

पाएण

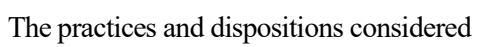

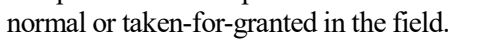

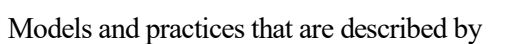

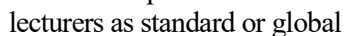

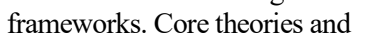

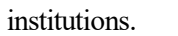

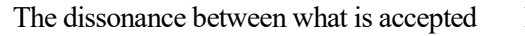

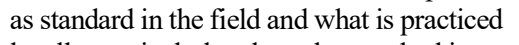

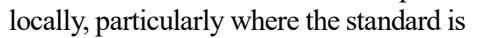

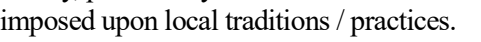

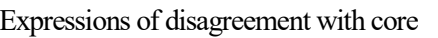

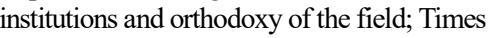

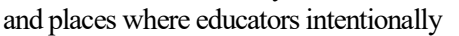

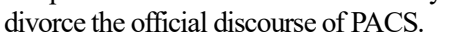




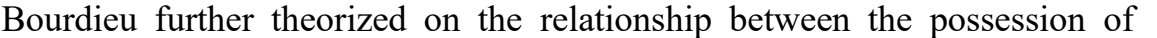

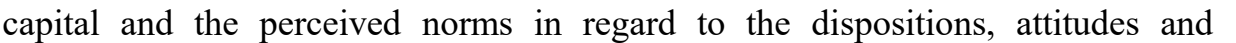

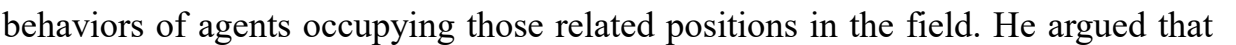
ए।

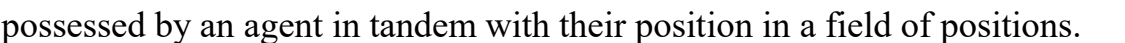

To illustrate Bourdieu's theory, consider that a multitude of educational

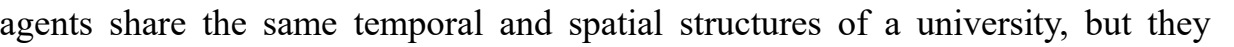

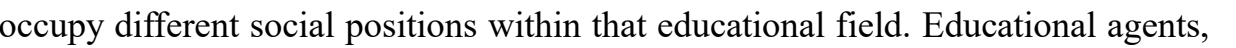

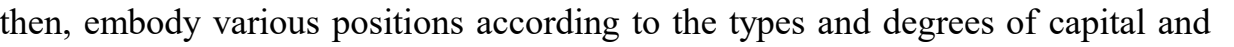

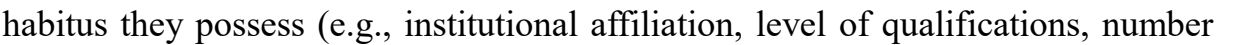

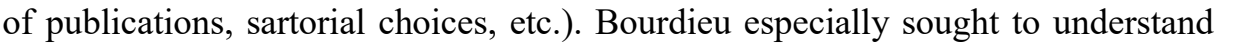

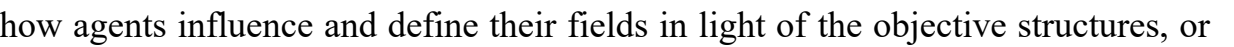

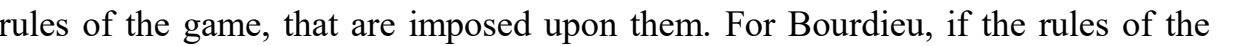

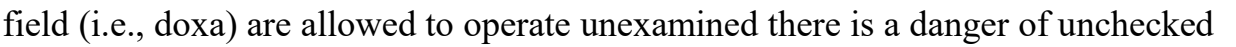

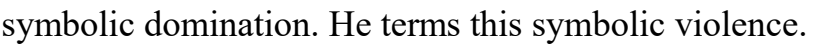

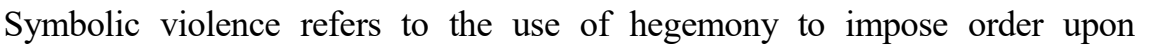

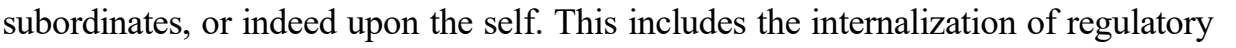
rules and patterns of behavior and thinking. Together with Galtung's notion of structural violence, Bourdieu's concept of symbolic violence offers a conceptual

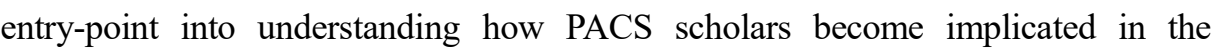
perpetuation of violence through their "good" work (Kester and Cremin 2017). This

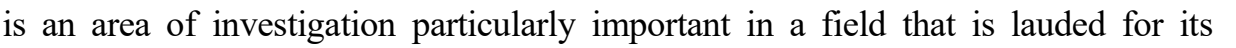

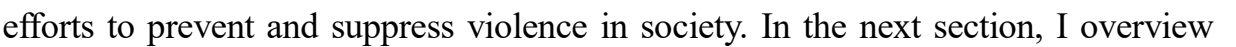

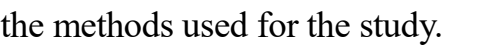

\section{METHODS}

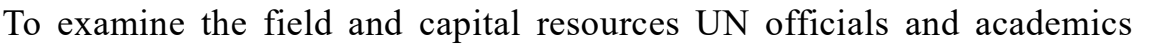

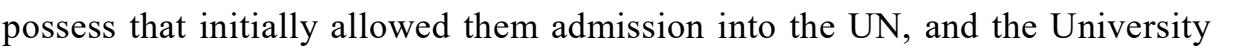

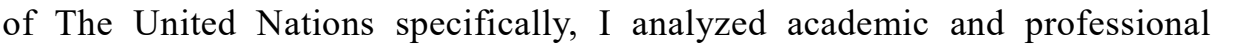

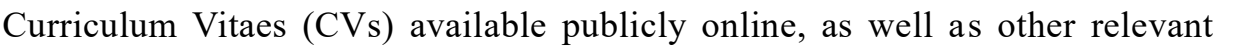
digital materials such as lecturers' online profiles and publications. I followed

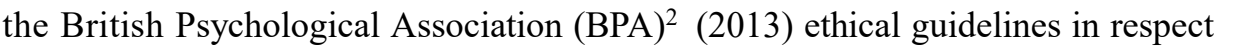

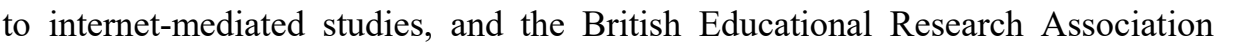

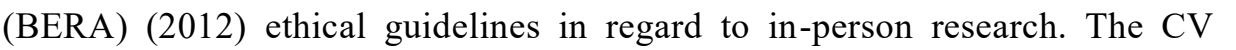

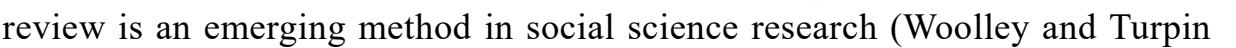

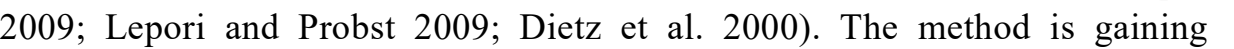

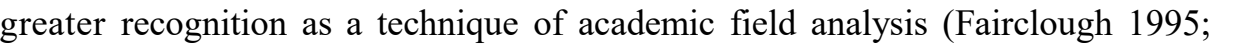

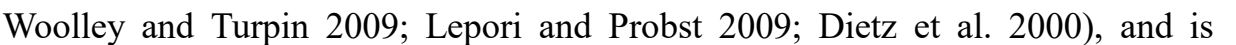

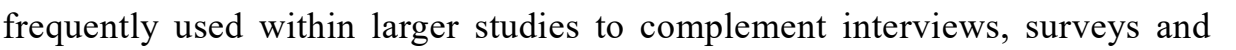

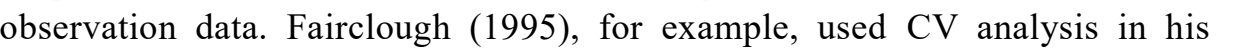




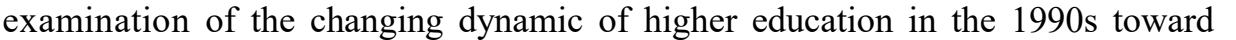

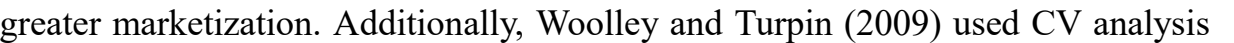
to examine the global migration of skilled researchers, what they refer to as "th $\square$ mobility of scientific and technical human capital" (145).

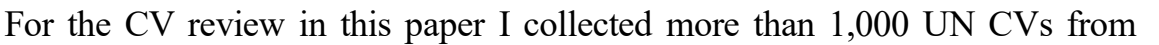

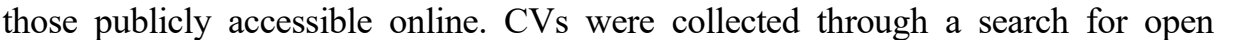

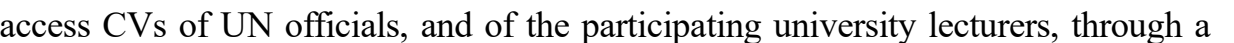
Google search for "United Nations CVs," "Curriculum Vitaes of UN officials," and "United Nations academic CVs," among other variations of these keywords. Those

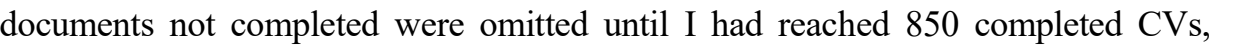

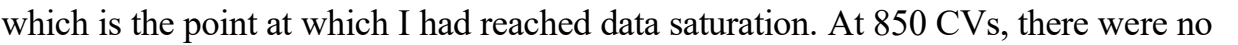

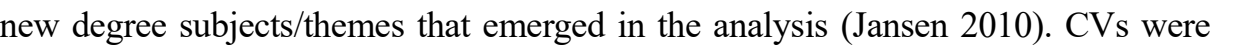

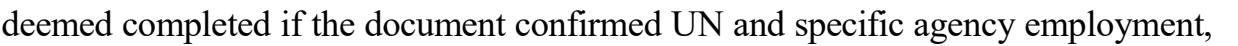

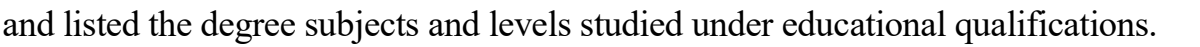

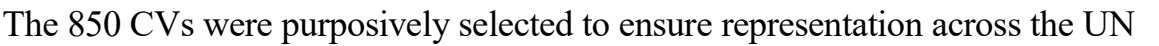

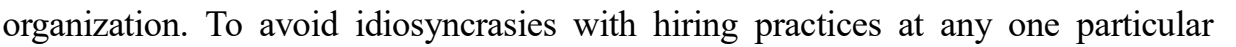

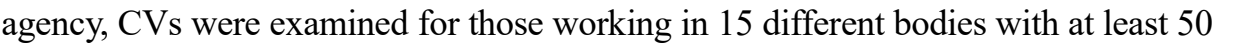

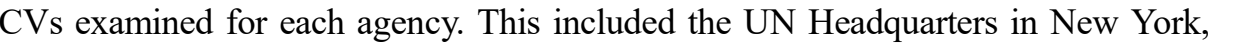
United Nations Development Program (UNDP), United Nations Children's Fund

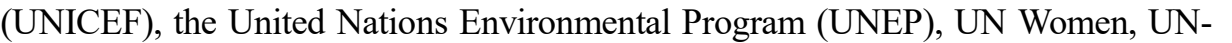

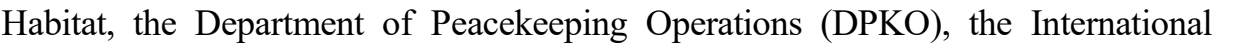

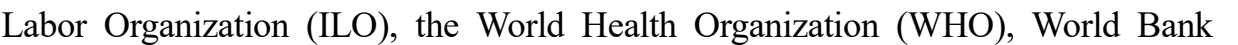
प

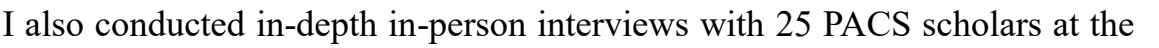

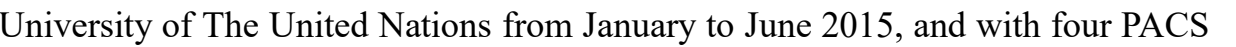

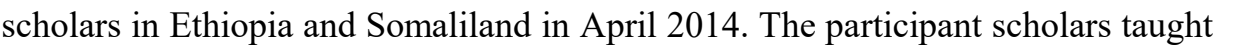

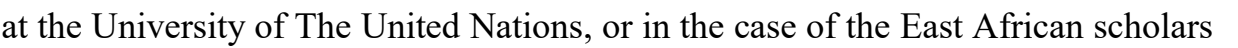

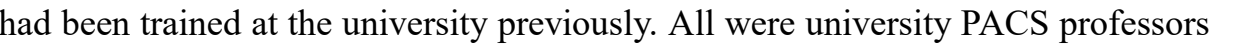

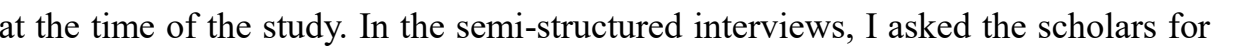
ए

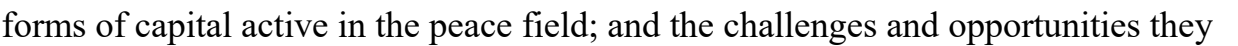

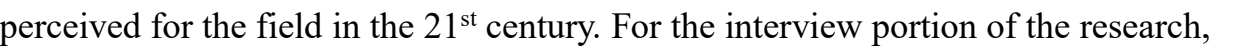

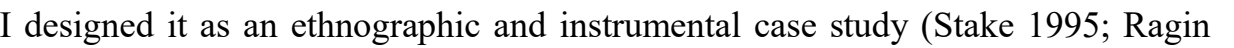

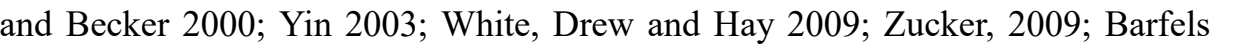

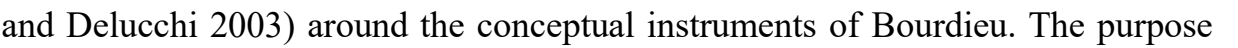

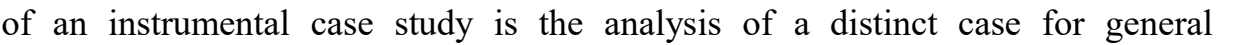

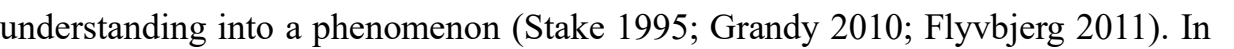

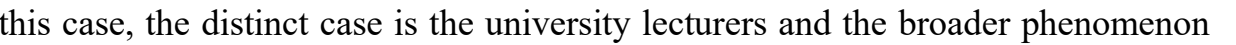

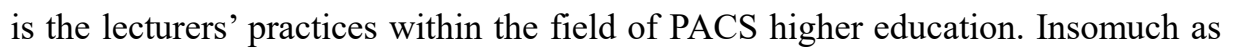

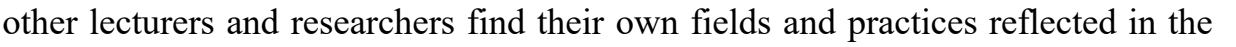

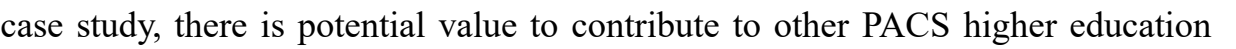




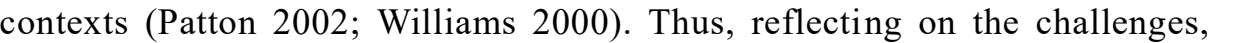

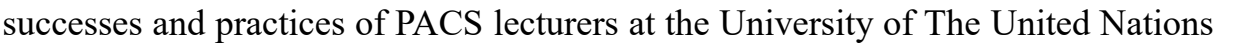

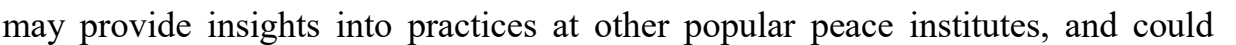

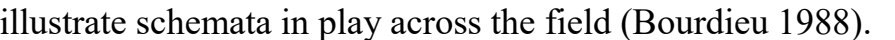

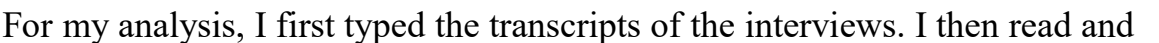
$\square$ read the transcripts and CV data multiple times, seeking elements from Bourdieu's

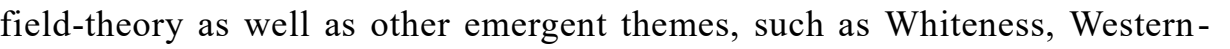

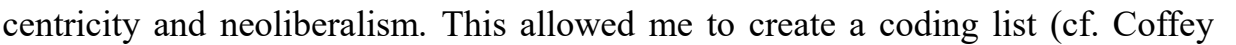

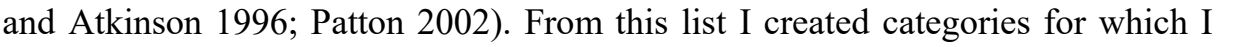

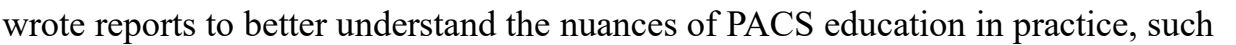

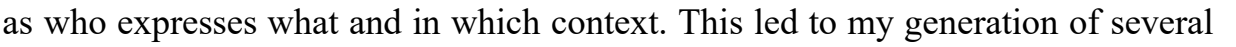

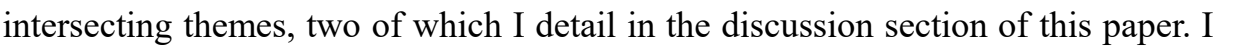

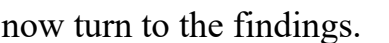

$\square$

\section{CURRICULUM VITAE FINDINGS}

\section{$\square$}

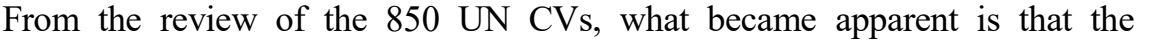

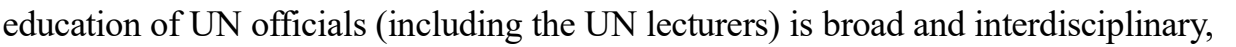

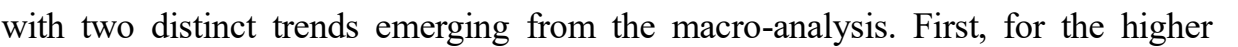

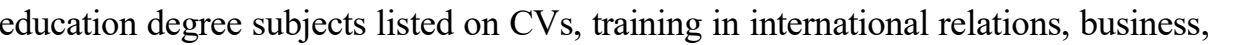

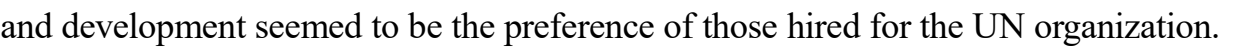

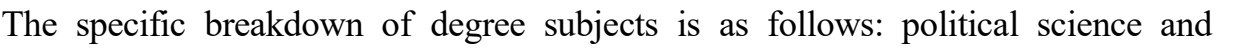

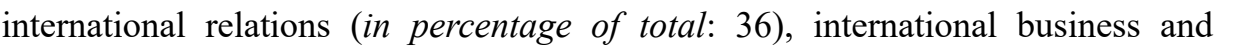

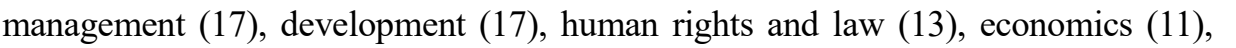

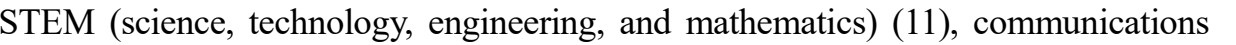

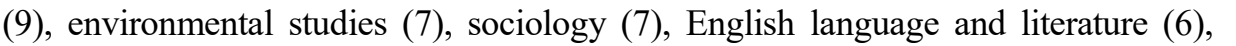

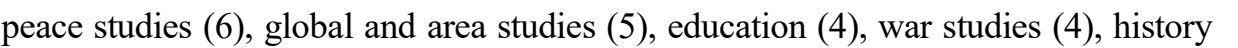

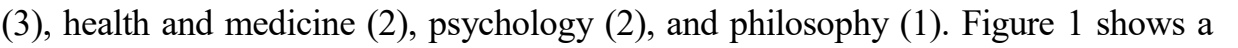

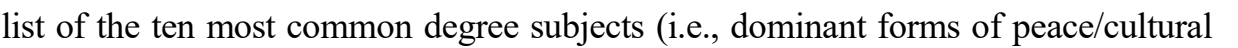

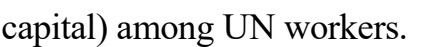

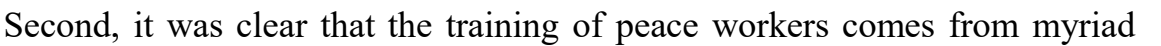

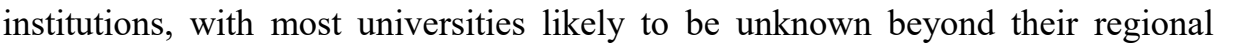

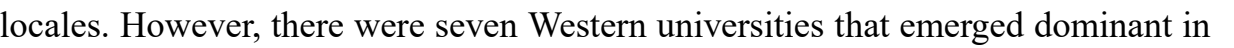

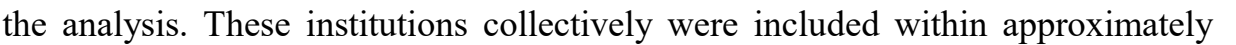

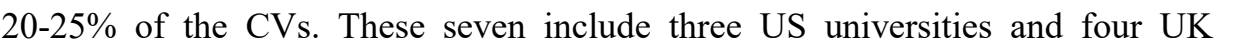

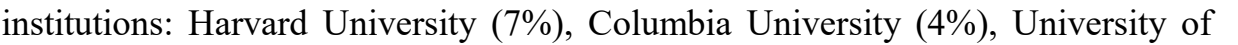

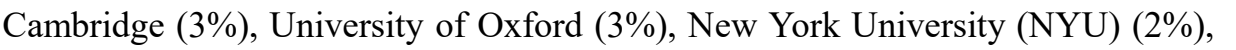

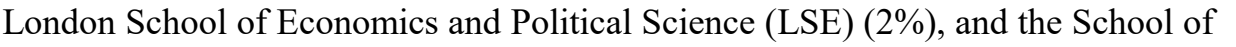

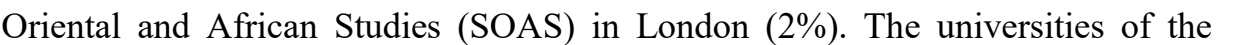

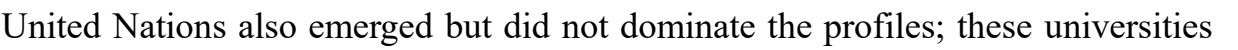

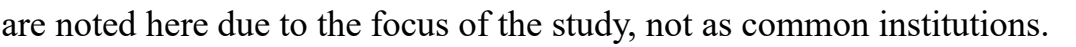




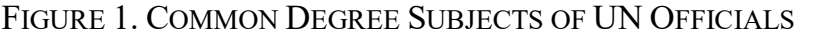
in

$\square \square \square\|ा\| \square$

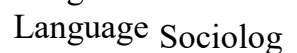

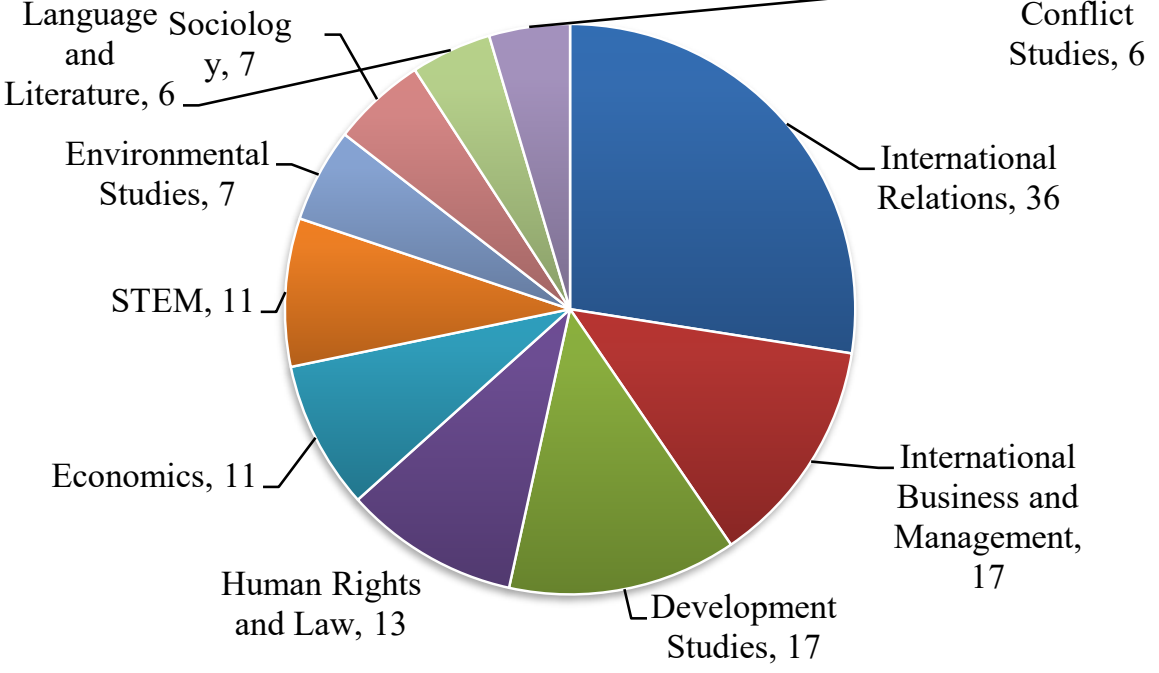

$\square$

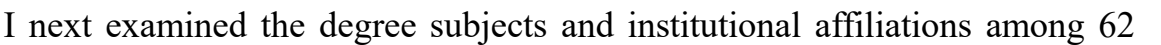

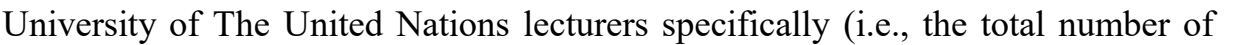

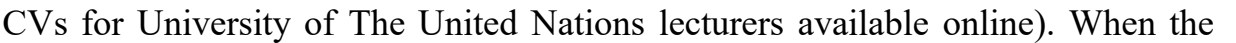

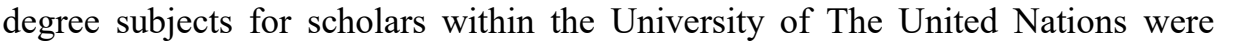

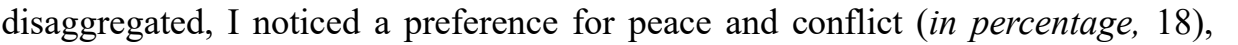

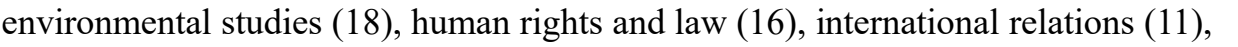

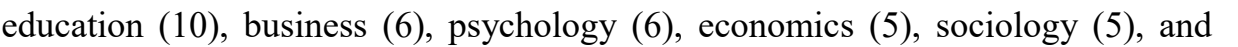

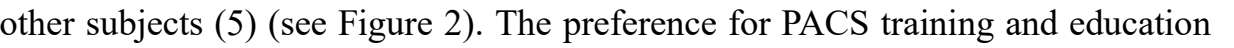

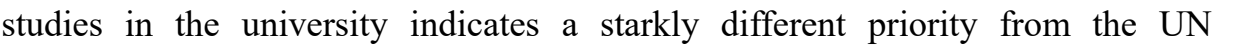

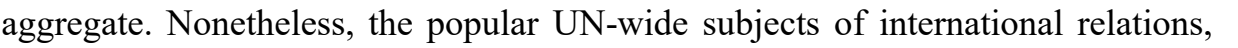

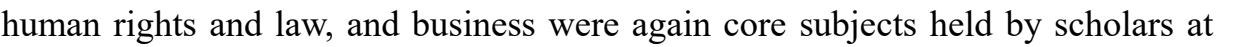

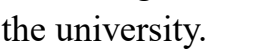

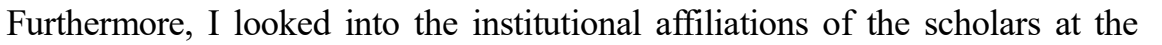

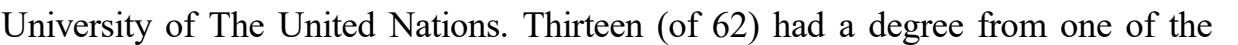

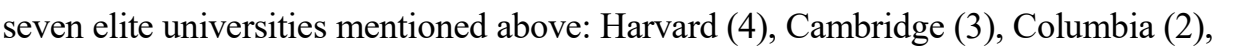

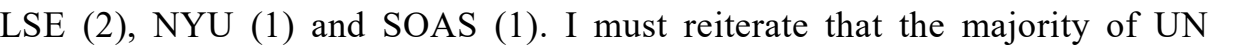

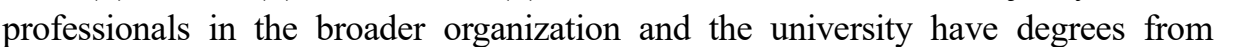
regional universities, challenging Bourdieu's reproduction theory. Nonethel $\square \square \square \square \square$

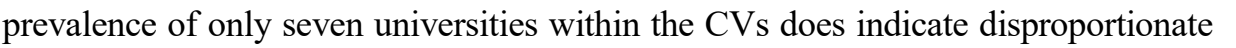

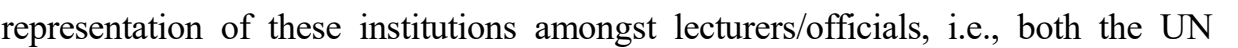

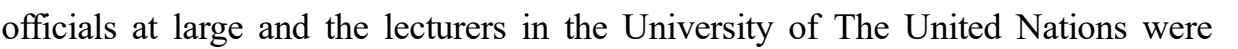

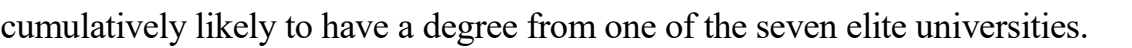




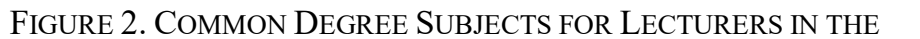

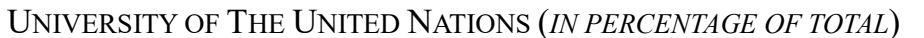

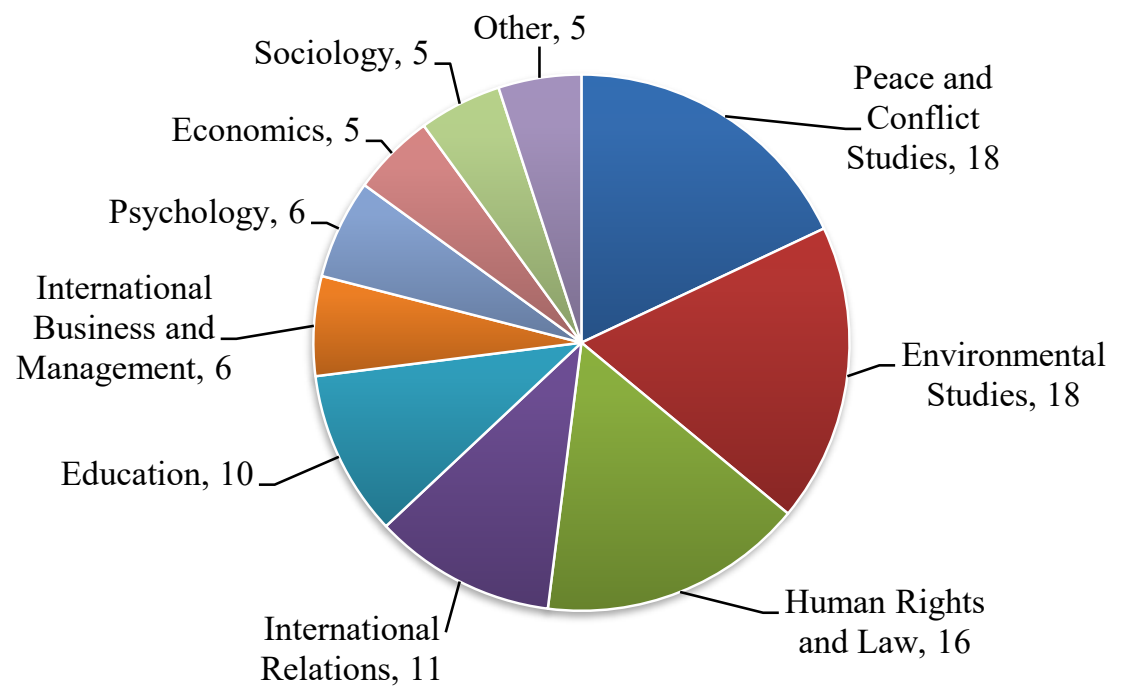

$\square$

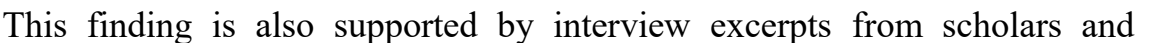

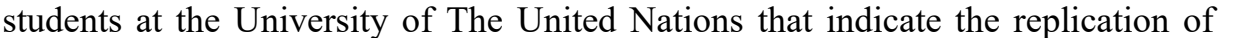

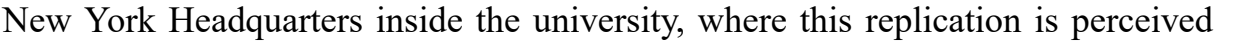

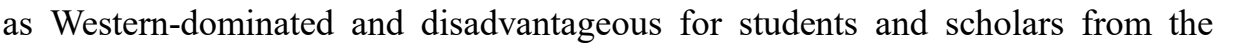

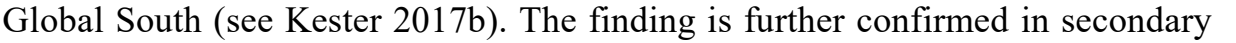

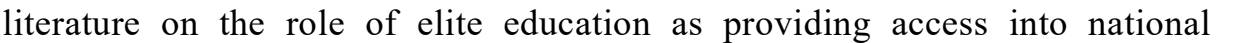
governments and multilateral organizations (O'Rourke, Hogan, and Donnelly

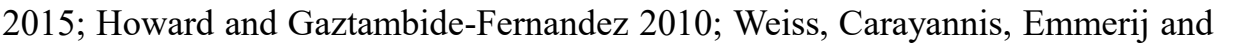

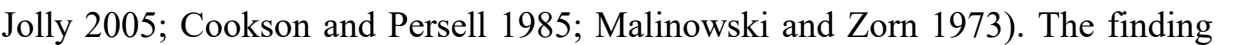

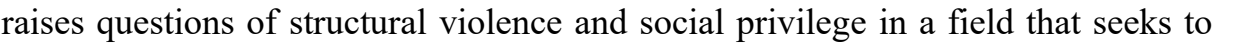

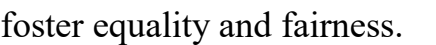

$\square \square\|\|\|\|\|\|\|\|\|\|$ ourdieu's concept of cultural capital to the CVs, it is

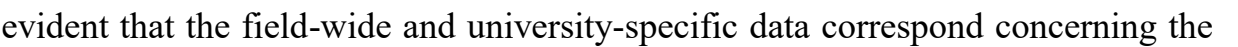

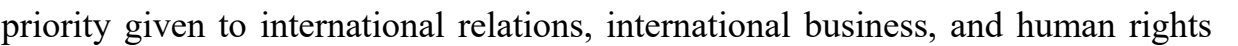

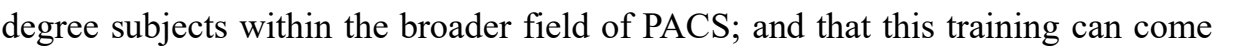

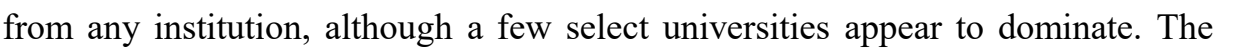

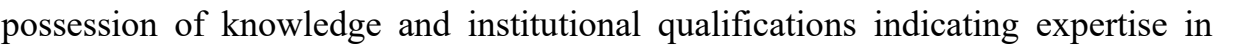

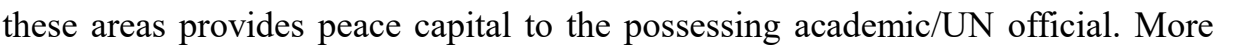

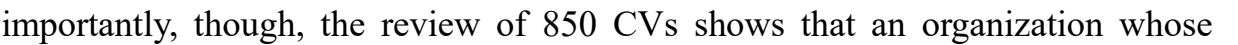

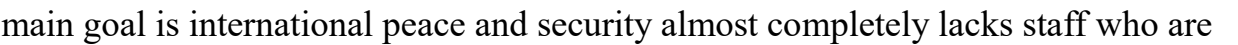

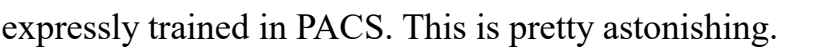

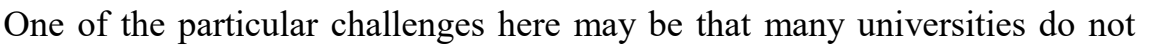

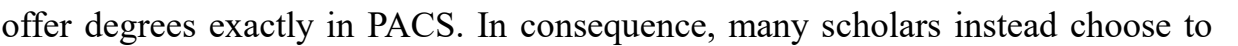




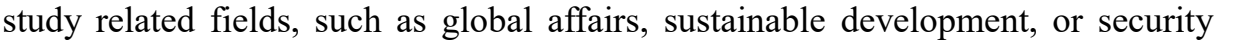

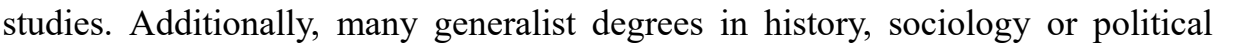

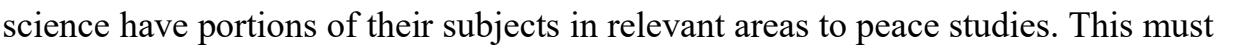

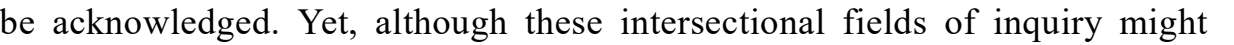

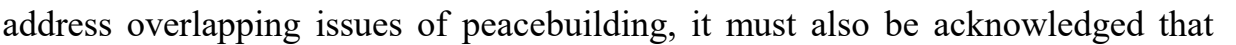

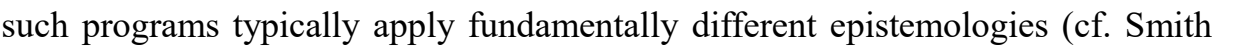

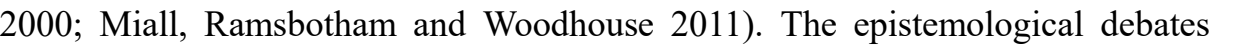

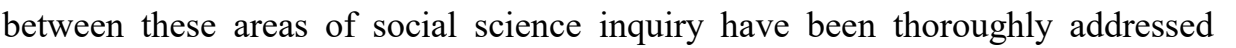

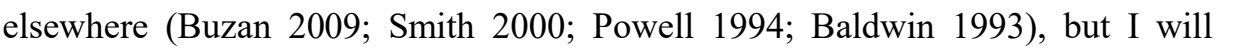

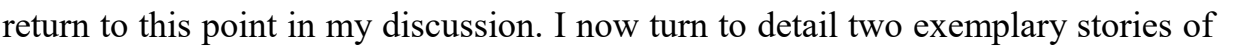

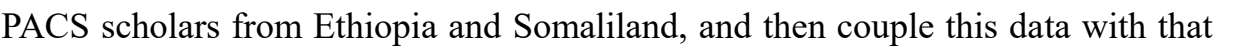

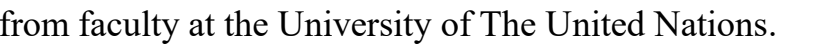

$\square$

\section{TWO CASES}

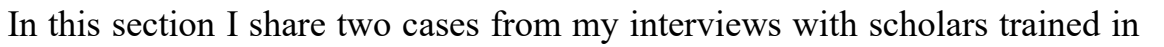

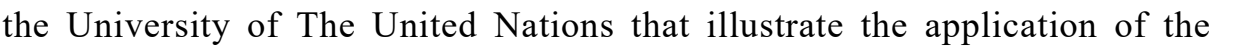

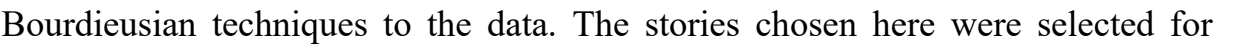

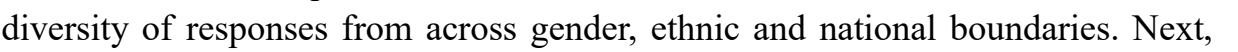

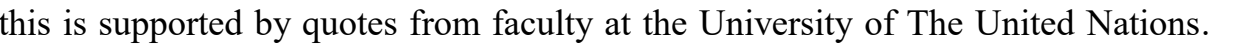

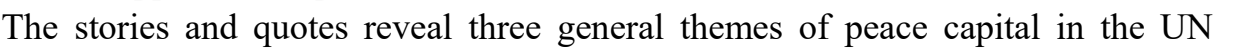

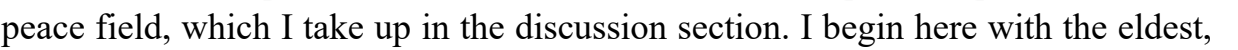
$\square \square \square \square \square \square$

$\square$

\section{Mohamed's Story}

$\square$

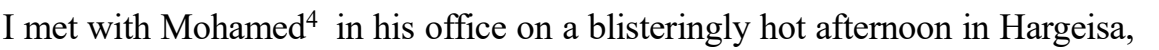

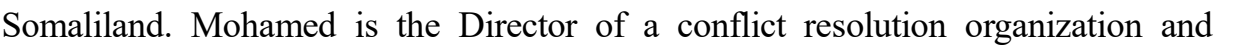

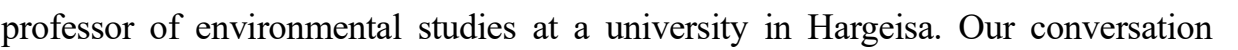

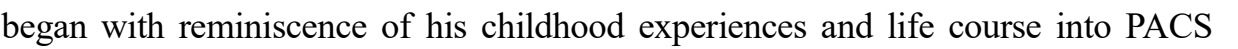

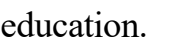

$\square$

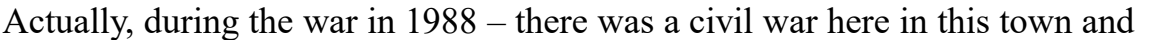

this part of the country, Somaliland, that's the northern part of Somalia, back

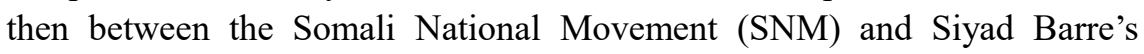

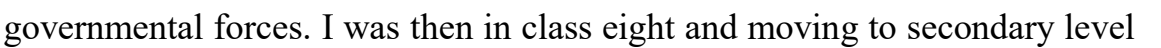

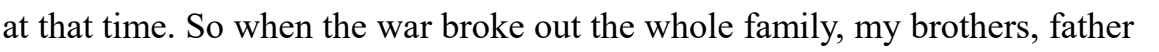

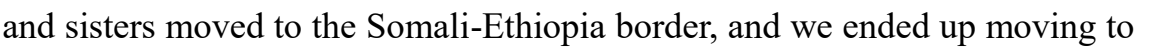

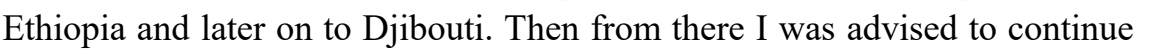

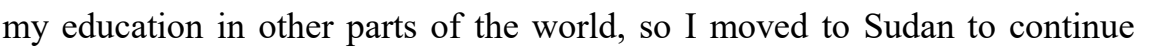
my secondary school... and then from there I moved to Nigeria to do my 


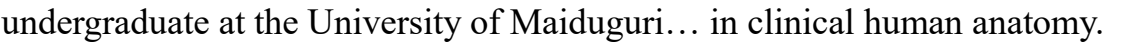
$\square$

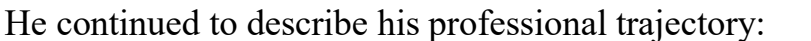

$\square$

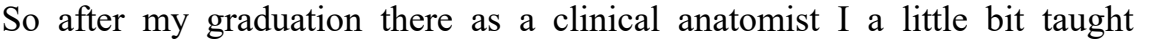
clinical medicine in Nigeria as a lecturer for one year... then in 2005 I

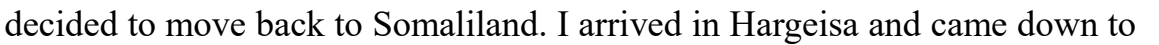
पाm

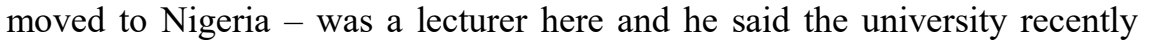

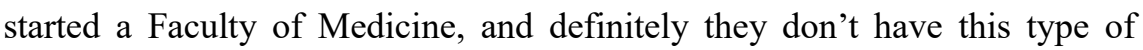
course here... I was there until the beginning of 2008, when I was appointed

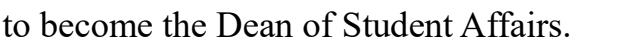

$\square$

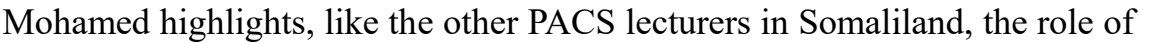

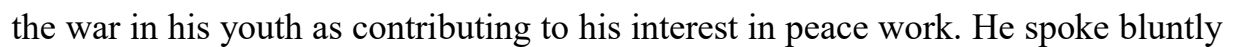

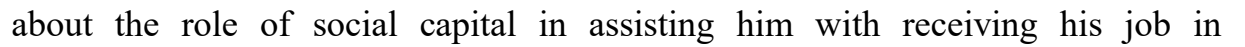

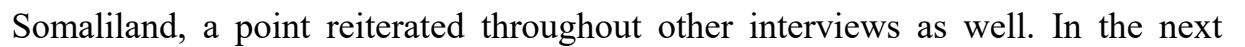

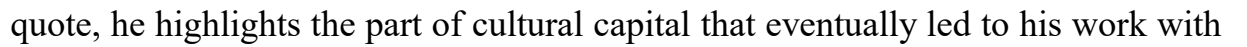
the university's Peace Institute.

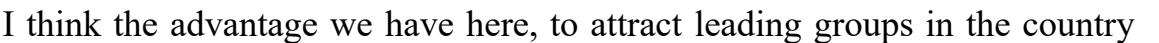

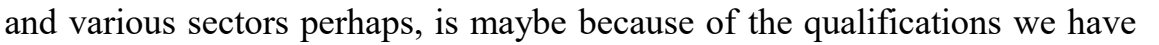

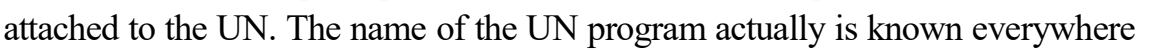
we go here... Maybe it's not big in other parts of the world... But wherever

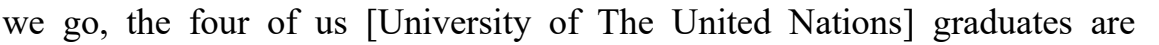

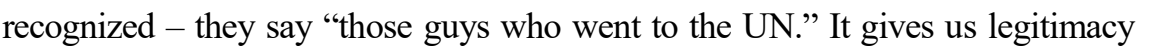
to teach and to lead the courses... the university and the UN in this context is

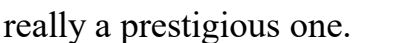

$\square$

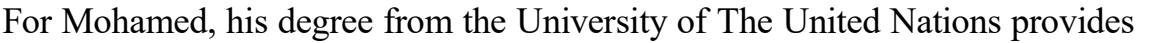

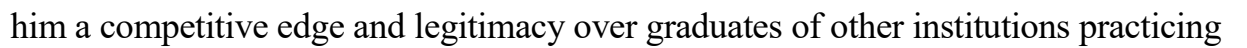

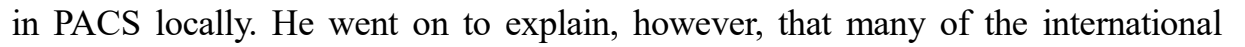

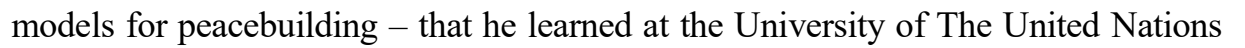

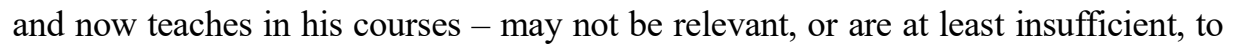

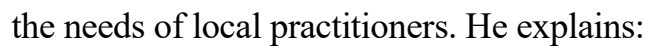

$\square$

The frameworks don't really carry over to Somaliland. There's no specific

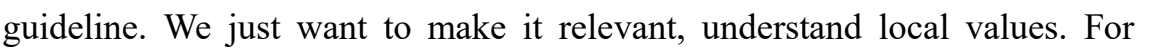

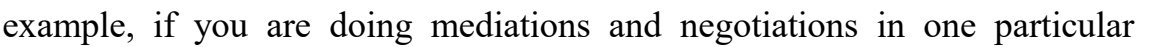

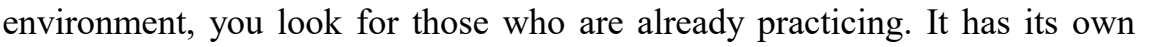
पा 
is happening locally. [...] I have had so many discussions with the leading peacebuilders in this society, and they said, "we have no model." There's nothing I can teach my kids; but we have some elders who if they say "stop the war," the war will stop... They aren't following procedures. When they speak to the parliament others listen... [they] can end conflict, but [their]

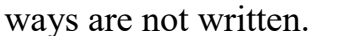

$\square$

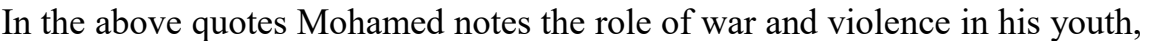

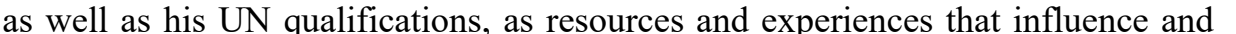
legitimize his peacebuilding work. These qualities relate to Bourdieu's habitus and

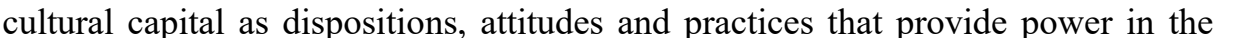

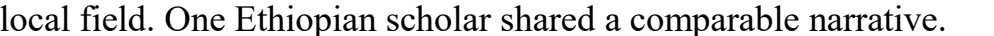

$\square$

\section{Aamina's Story}

I interviewed Aamina on a hot day in April 2014 in a Kaldi's coffee shop in

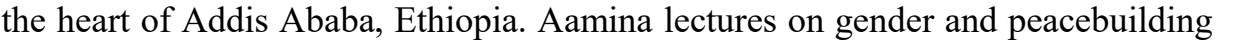

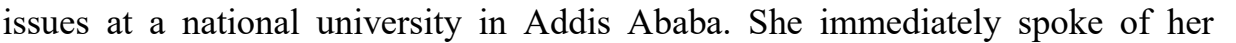

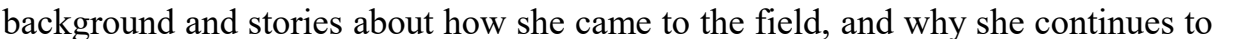

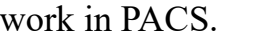

$\square$

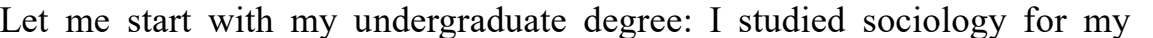

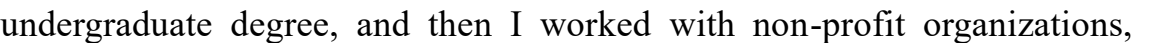

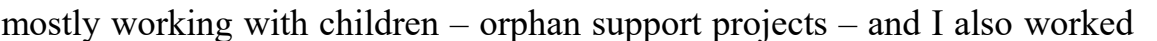

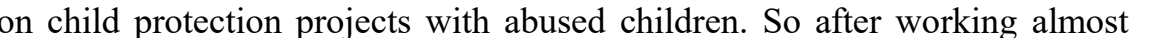

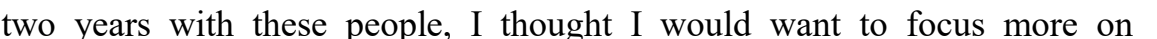
women's rights issues and on gender and peacebuilding, so I went to the

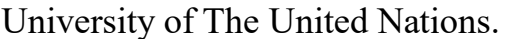

$\square$

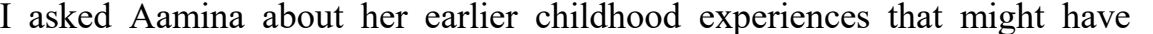

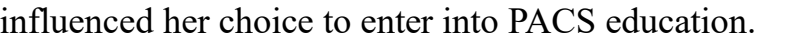

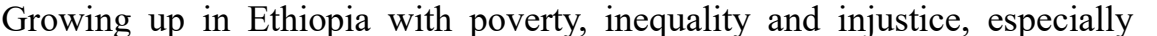

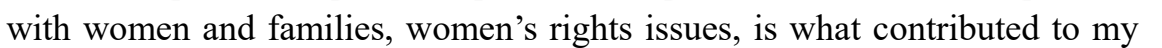
work. It's always men who are the breadwinners and benefit from the system,

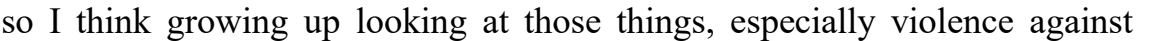

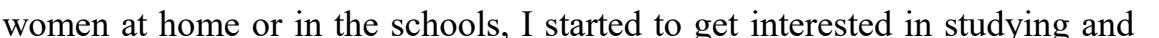

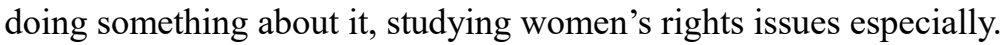
$\square$

She explained how this desire to study women's rights issues led her to the

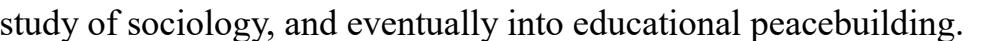




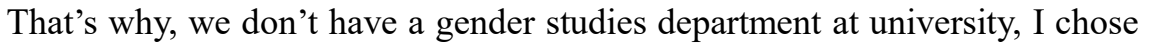

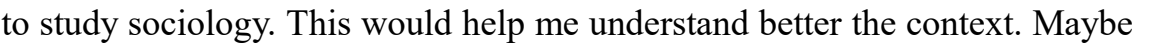

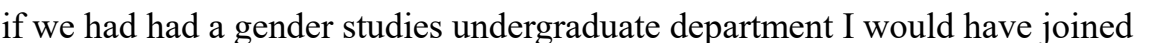
that... that's why I went to sociology.

From Aamina's story it is clear that an

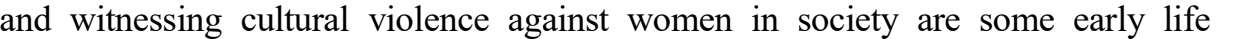

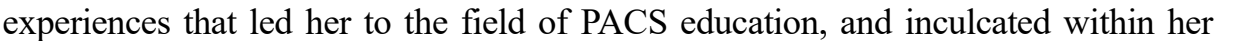

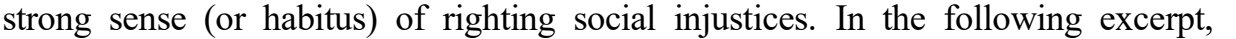

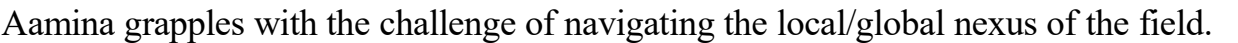

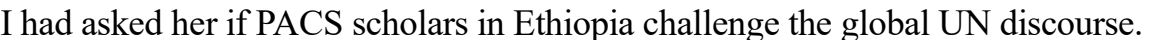

$\square$

$\square \square \square$ not so much... In a way this is also because the field $\mathrm{i}\|\|\|\| \| \square$ developed in the country. And it's because if you start for instance when you are teaching you talk about those kinds of issues, challenging those things... It's very difficult, because people are just being introduced to these types of

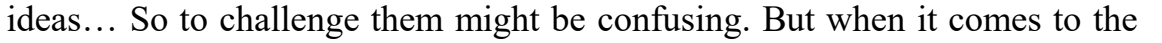

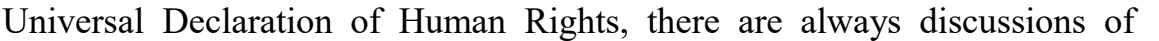

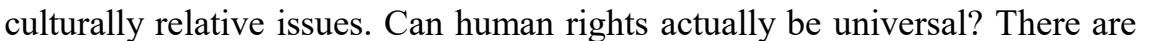

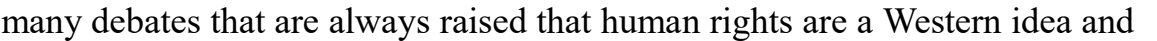

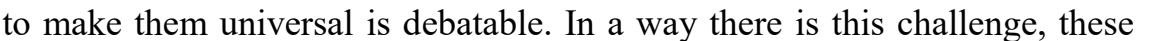

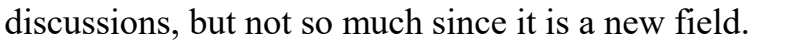

$\square$

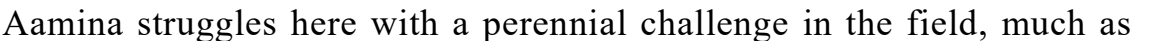

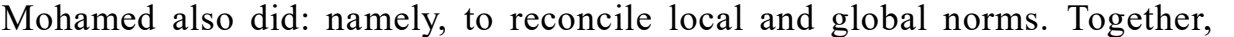

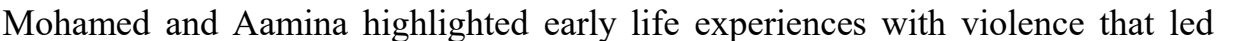

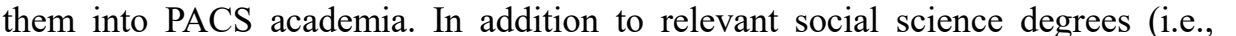

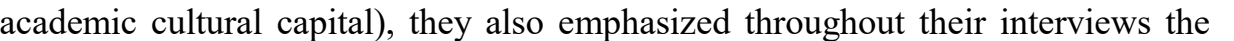

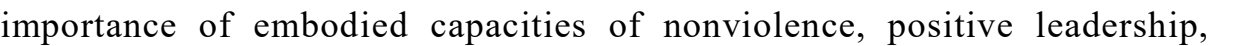

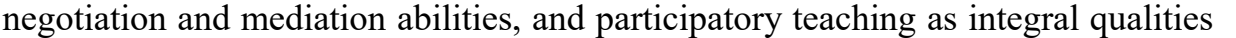

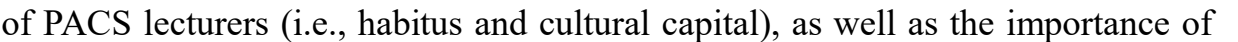

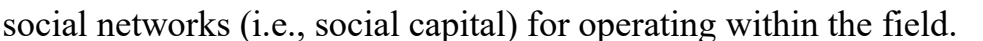

$\square$

\section{SUPPORT FOR THESE TWO CASES}

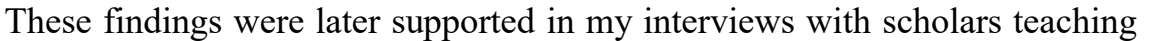

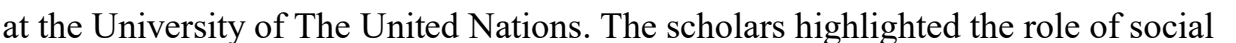

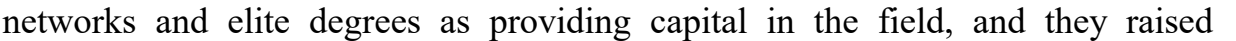

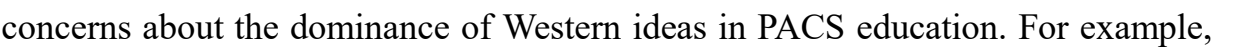

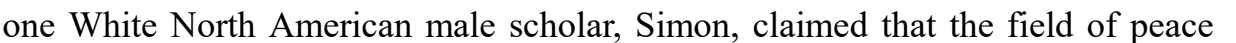

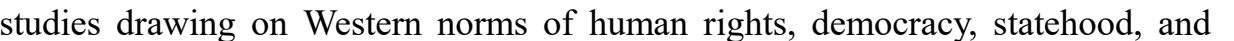




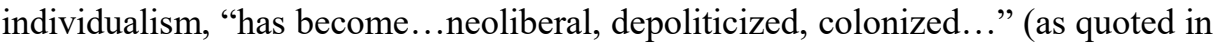

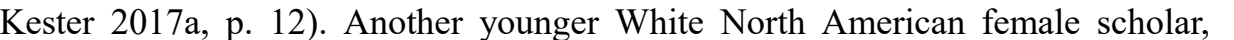
Cindy, agreed: "The colonization of the field, it really is Westernized" (quoted in

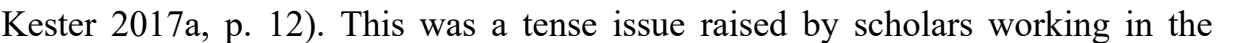

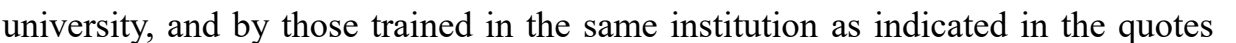

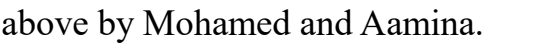

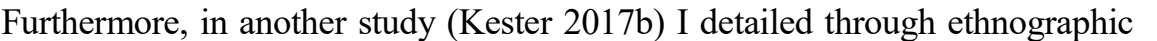
means how the use of "Bourdieu's concept of symbolic violence points to the ways

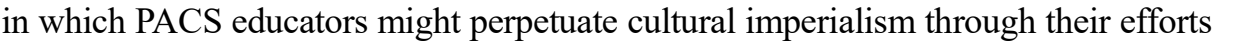

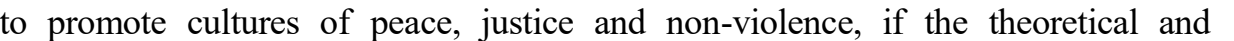
pedagogical assumptions of the field...remain unexamined" (p. 3). In that same

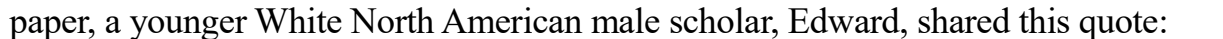

$\square$

I don't think it's a 100\% replication of Western society, but if you're trying $\square$ find one dominant cultural paradigm behind the school it's not Chinese,

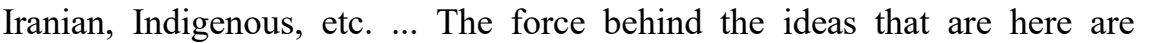

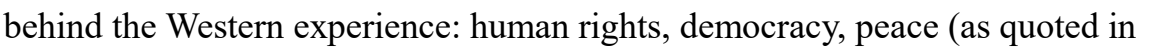

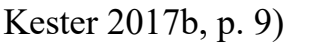

$\square$

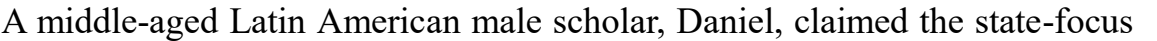
of the UN to be the major "obstacle": $\square$

$\square \square$

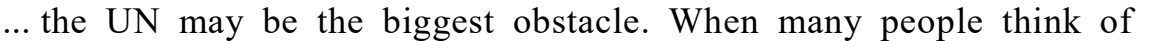

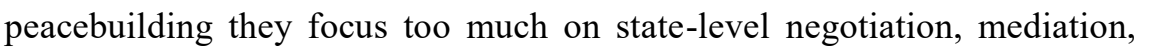

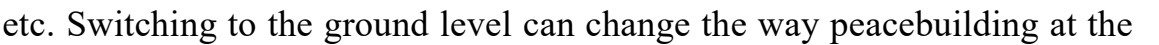

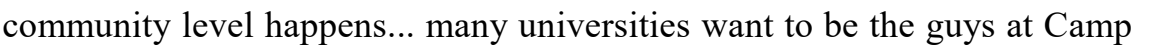

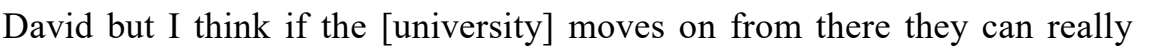

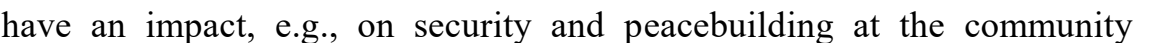
level... (as quoted in Kester 2017a, p. 10).

$\square$

Simon concurred, "[In the field] the state is not really questioned; it's taken

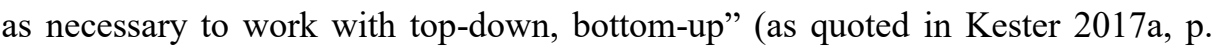

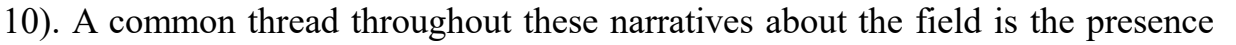

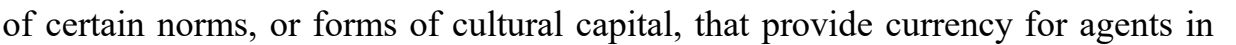
ए ए

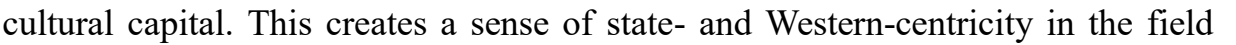

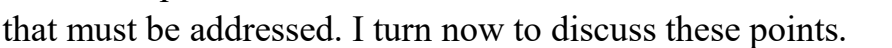

\section{DISCUSSION}

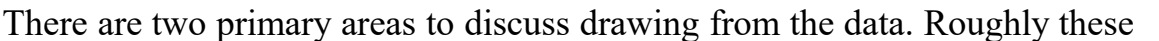




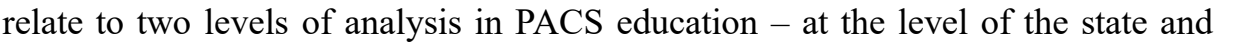

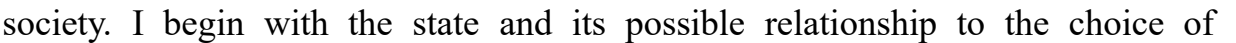
पाm

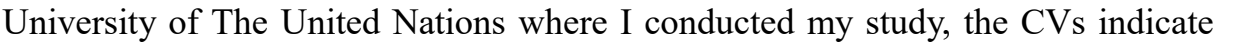

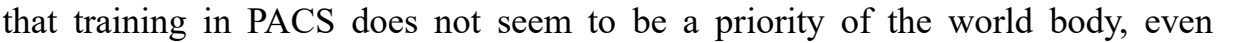

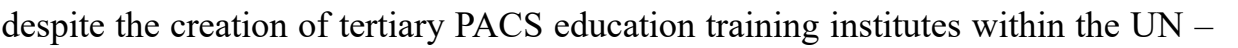

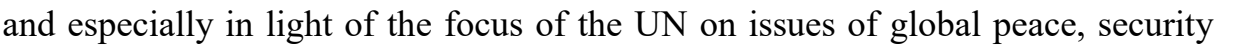

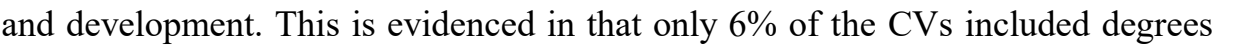

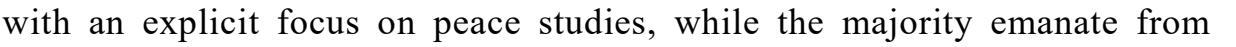

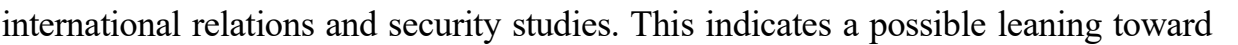

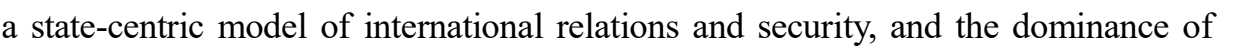

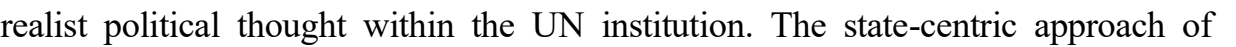

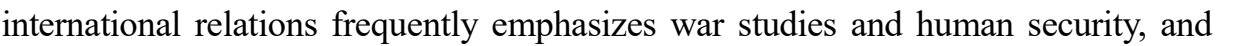

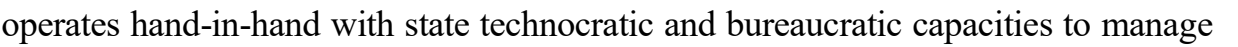

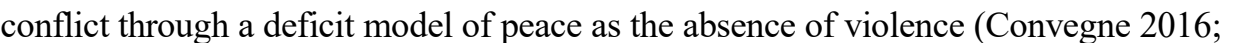

Cremin 2016; MacGinty 2012), i.e., a "security first" strategy to peacebuilding

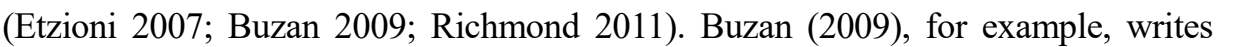
$\square\|\|\|\|\|\|$ ecurity studies in international relations, it "is essentially about the impact of military technology on relations between states" (p. 217).

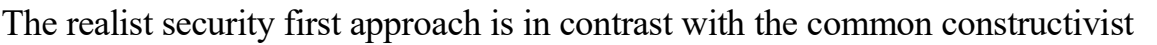

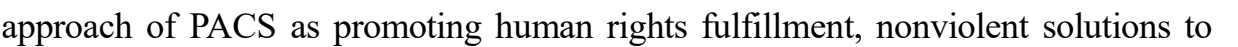

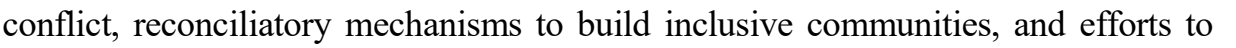

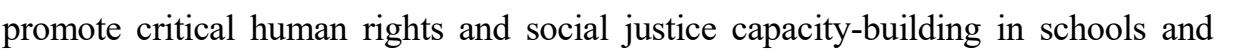

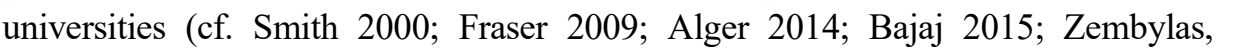

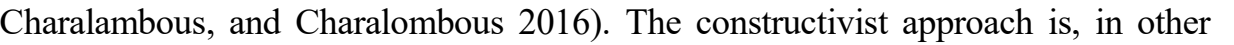

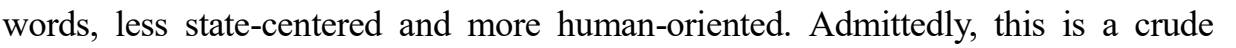

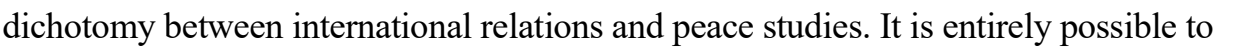

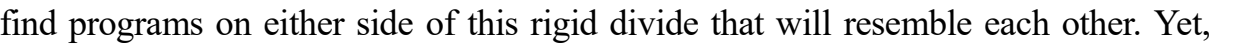
ए

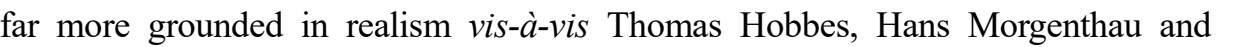

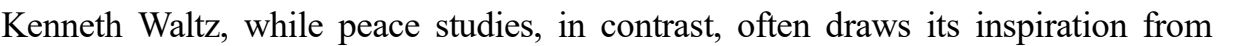

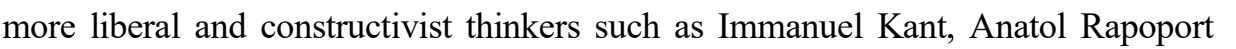

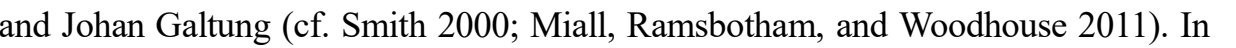

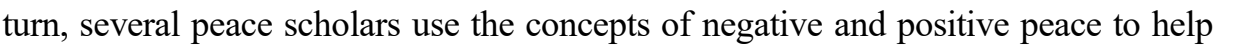

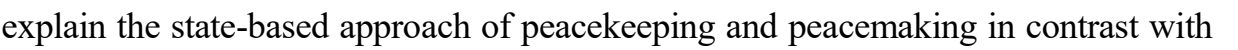

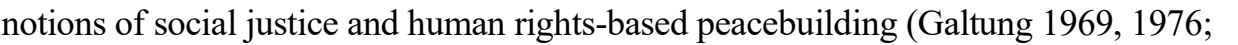

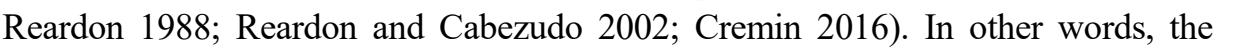

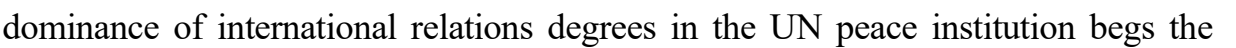

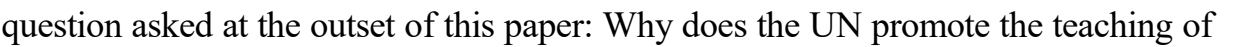

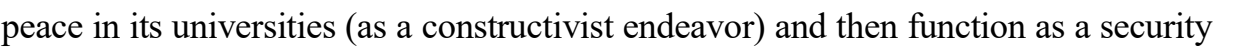

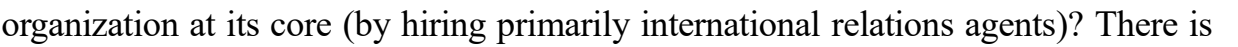




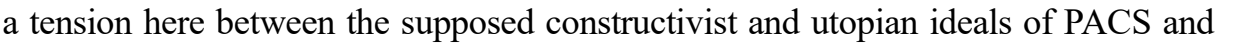

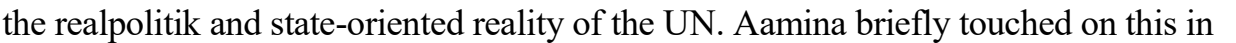

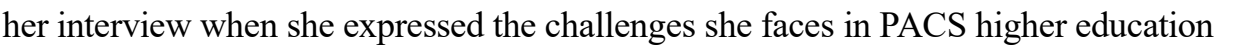

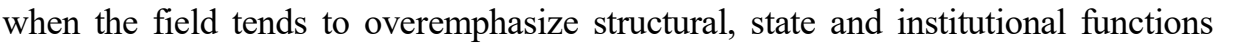

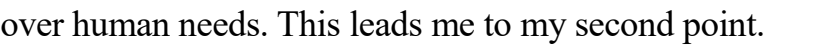

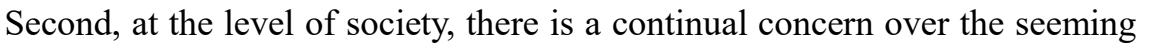

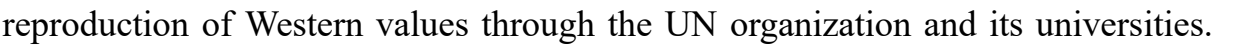

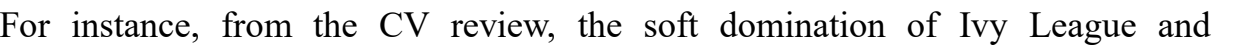

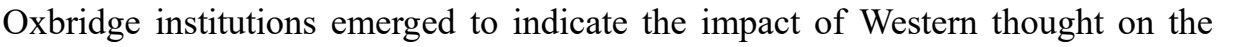

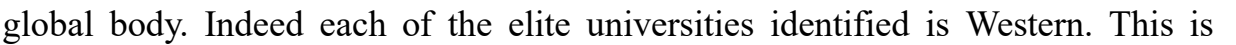

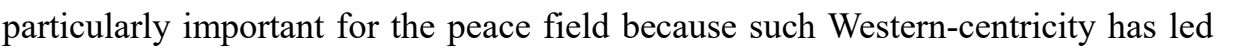

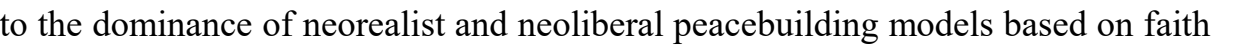

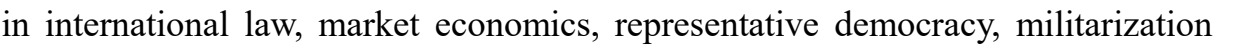

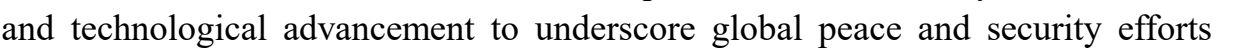

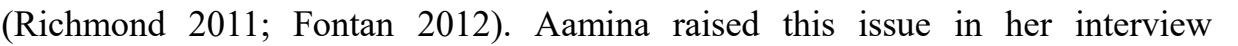

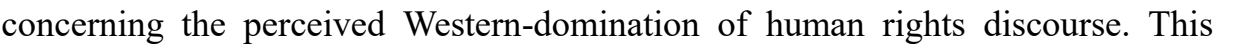

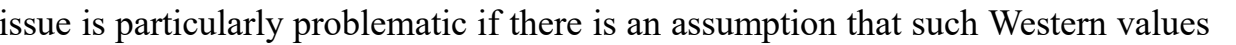

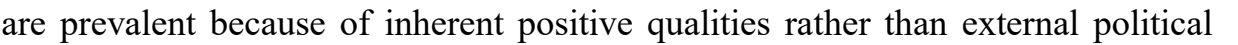

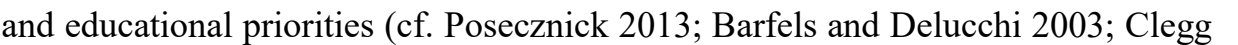

\section{$\square\|\|\|\|$}

Thus, the field seems to have drawn its "theoretical and methodological apparatus from [Western]... cognate social sciences," such as politics, anthropology,

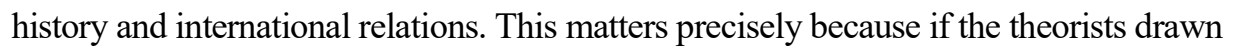
upon are primarily Western, and if these theorists are shown to lack "an understanding

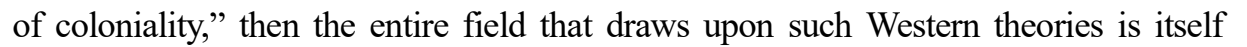

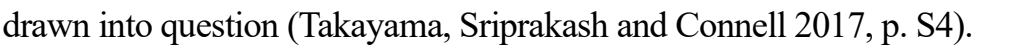

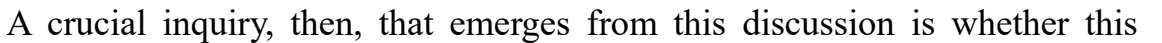

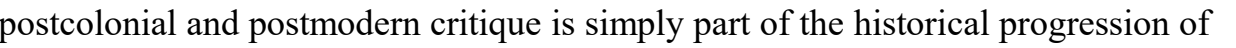

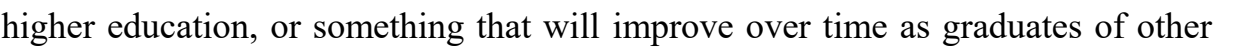

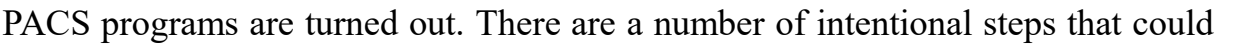

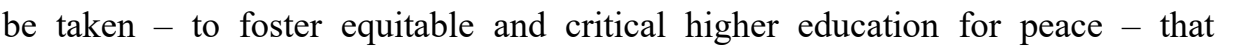

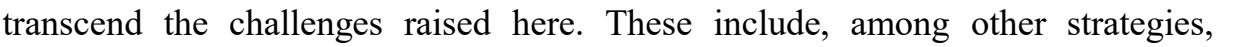

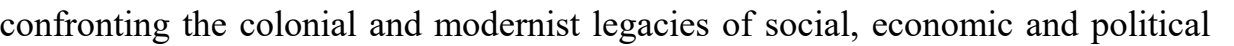
पा

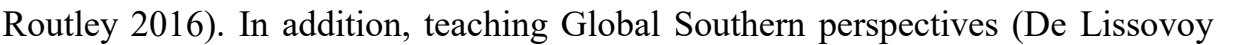

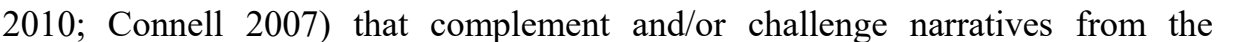
industrialized world, and that especially disrupt "the danger of a single story" in

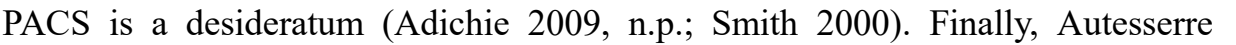

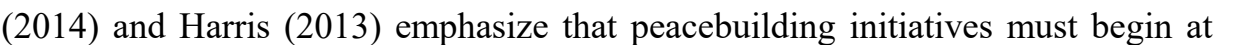

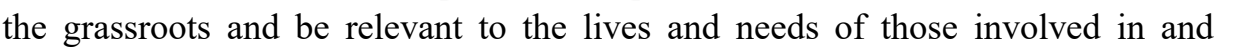

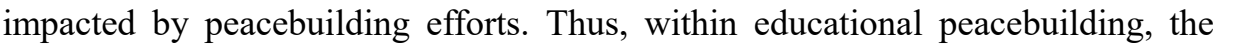




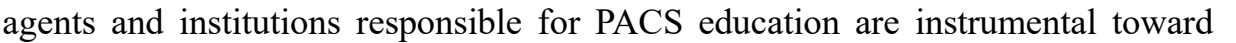

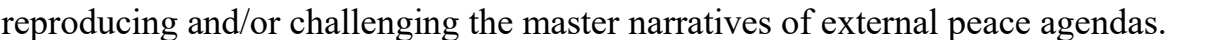

$\square$

\section{CONCLUSION}

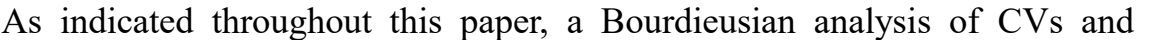

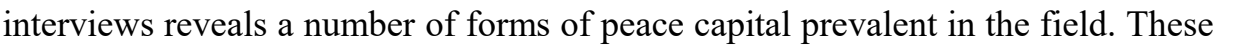

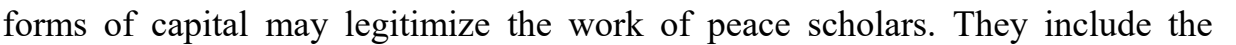

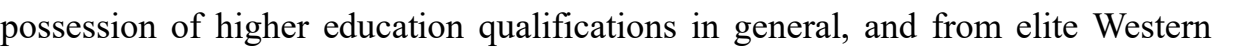

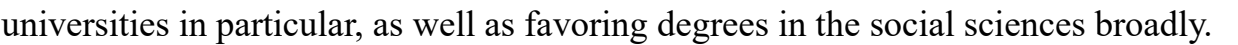

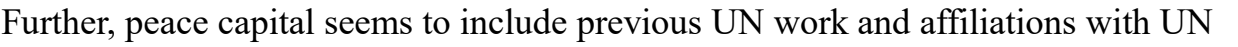
ए

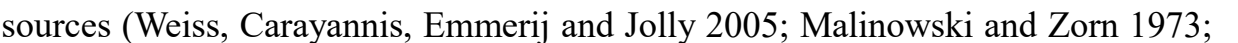
O'Rourke, Hogan, and Donnelly 2015). The findings from the CV data were

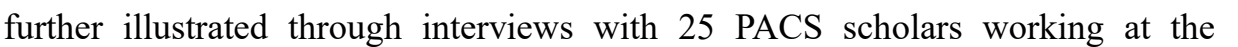

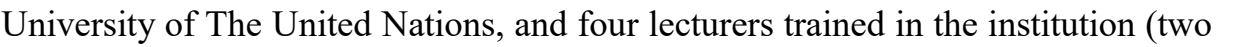

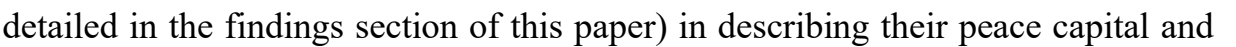

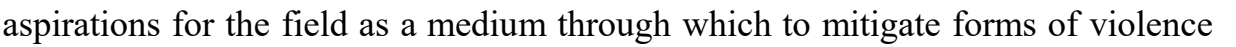
ए

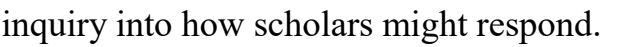

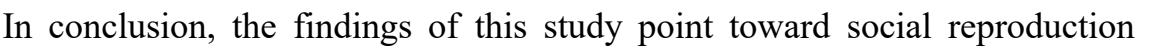

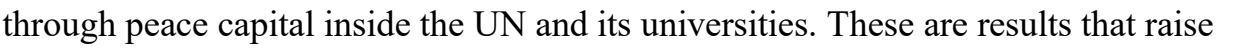

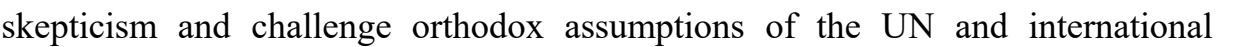

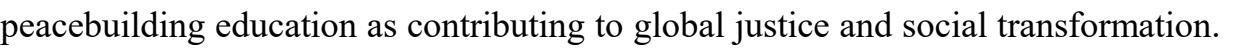

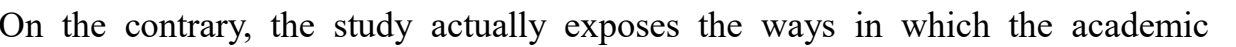

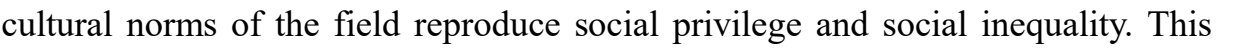

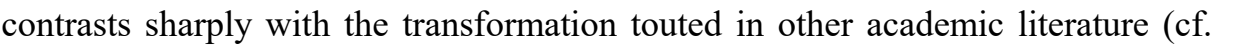

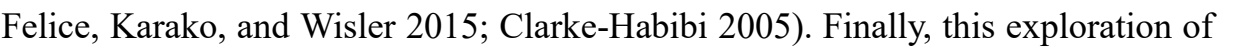

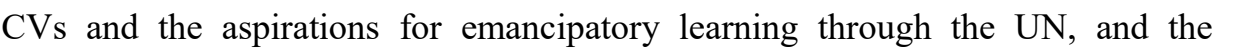

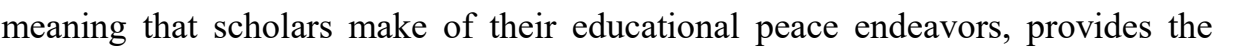

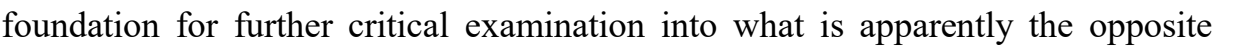

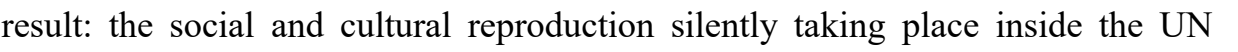

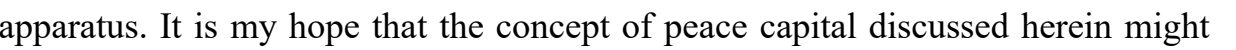

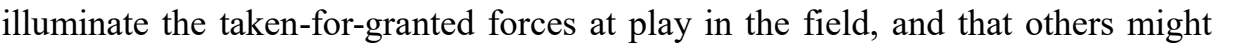

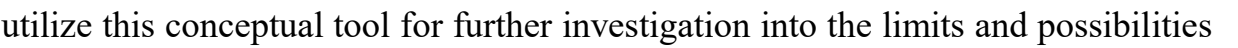

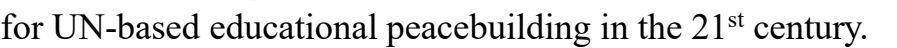

$\square$

\section{REFERENCES}

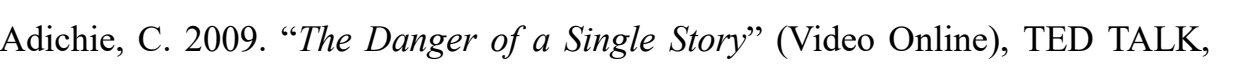

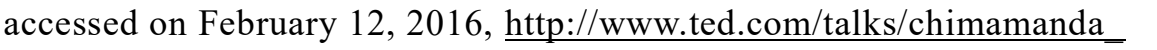




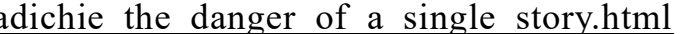

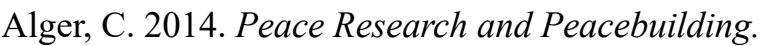

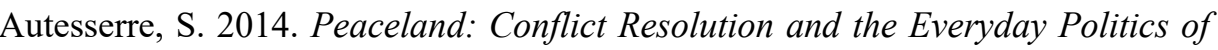

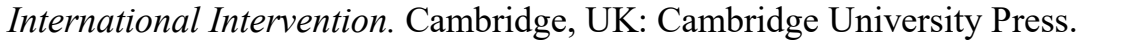
Bajaj, M. 2015. “'Pedagogies of Resistance' and Critical Peace Education Praxis.” Journal of Peace Education

Baldwin, D. 1993. "Neoliberalism, Neorealism, and World Politics." In D.

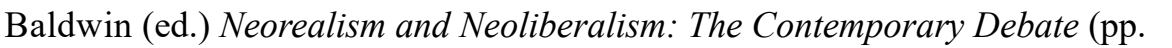

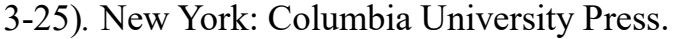

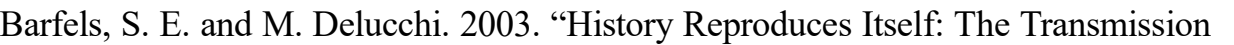
of Symbolic Capital at a Private Liberal Arts College in the USA.” Teaching in Higher Education $\square\|\|\|\| \| \square$

Bickmore, K. 2013. "Peacebuilding through Circle Dialogue Processes in Primary Classrooms: Locations for Restorative and Educative Work." In Restorative Approaches to Conflict in Schools: Interdisciplinary Perspectives on Whole School Approaches to Managing Relationships,

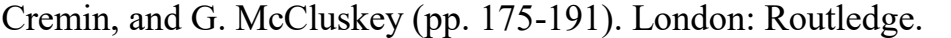

Bickmore, K. 2017. “Conflict, Peacebuilding and Education: Rethinking Pedagogies in Divided Societies, Latin America, and Around the World.” In K. Bickore

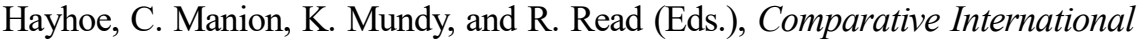

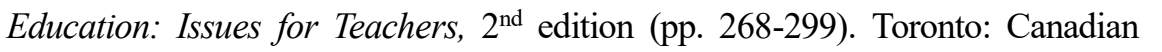

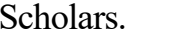

Borel, R., V. Cawagas, A. Jimenez and N. Salvetti. 2011. "Education for Sustainable Development at the University for Peace." Journal of Education for Sustainable Development $\square\|\|\|\| \| \square$

Bourdieu, P. 1986. "The Forms of Capital." In Handbook of Theory and Research for the Sociology of Education,

$\square \square \mid\|\|\|\|\|\| \|$ Homo Academicus.

Bourdieu, P. 1989. "Social Space and Symbolic Power.” Sociological Theory $\square \square$ पा\|ा\|ा

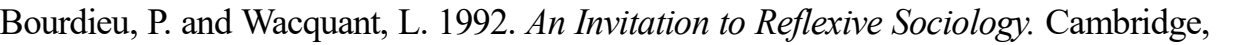

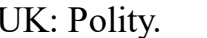

$\square \square$ nes, A. 1994. “An Integral Model of Peace Education.” In A. Wenden (Ed.),

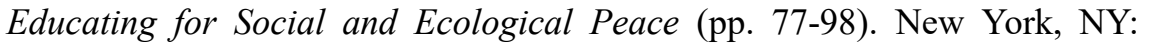

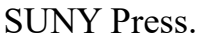

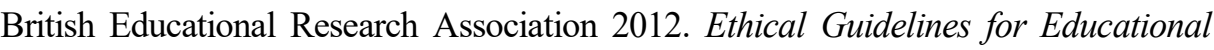

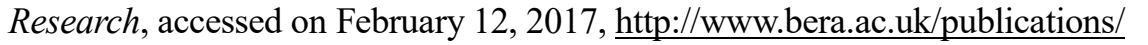

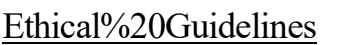

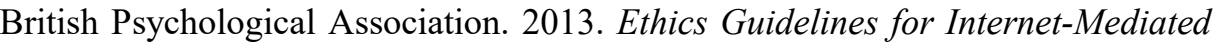

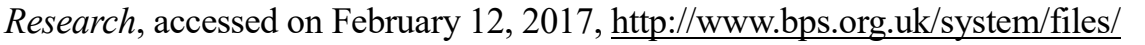


Clandinin, D. J. and M. F. Connelly. 1996. “Teachers' Professional Knowledge

Schools." Educational Researcher

पाणमHabibi, S. 2005. "Transforming Worldviews: The Case of Education for

Peace in Bosnia and Herzegovina." Journal of Transformative Education $\square$

Clegg, S. 2016. "The Necessity and Possibility of Powerful 'Regional' Knowledge:

Curriculum Change and Renewal." Teaching in Higher Education

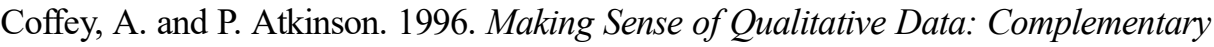

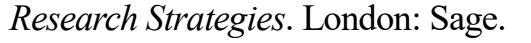

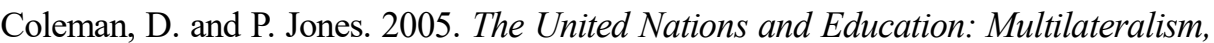

Development and Globalization.

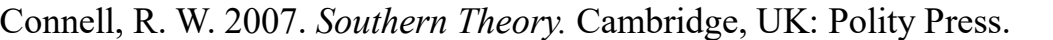

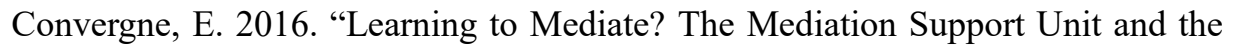

Production of Expertise by the UN." Journal of Intervention and Statebuilding $\square$

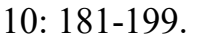

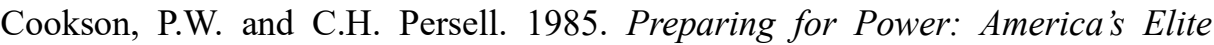

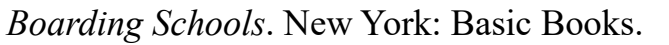

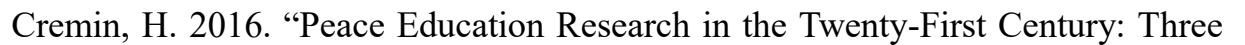

Concepts Facing Crisis or Opportunity?” Journal of Peace Education $\square \square$

$\square \| 10$

De Lissovoy, N. 2010. "Decolonial Pedagogy and the Ethics of the Global."

Discourse: The Cultural Politics of Education

Dibben, N. 2004. "How is the War on Iraq Relevant to Teaching and Learning in the UK?" Teaching in Higher Education

Dietz, J., I. Chompalov, B. Bozeman, E. Lane and J. Park. 2000. "Using the

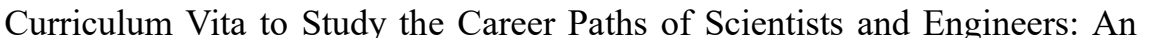

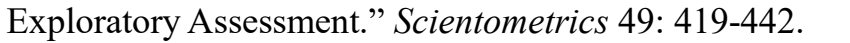

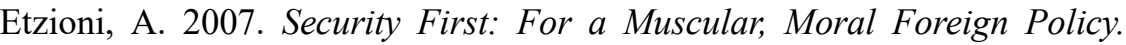

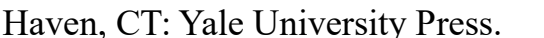

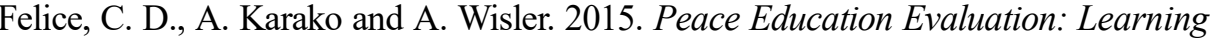

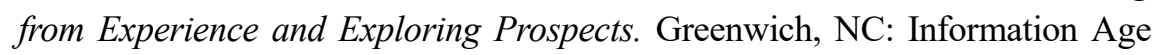

Flyvbjerg, B. 2011. "Case Study.” In The SAGE Handbook of Qualitative Research, $4^{\text {th }}$ edition,

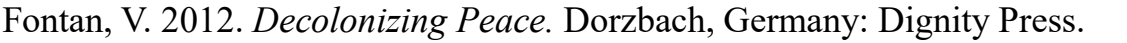

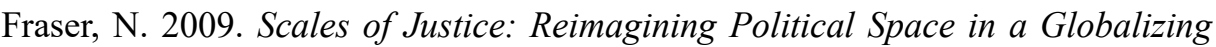

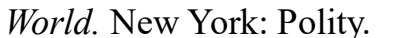

Galtung, J. 1969. "Violence, Peace, and Peace Research." Journal of Peace 
Research $\square\|\|\|\| \| \square \square$

Galtung, J. 1976. "Three Approaches to Peace: Peacekeeping, Peacemaking and

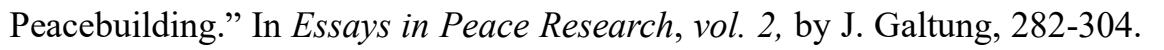

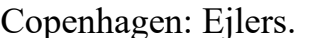

Grandy, G. 2010. "Instrumental Case Study." In Encyclopedia of Case Study

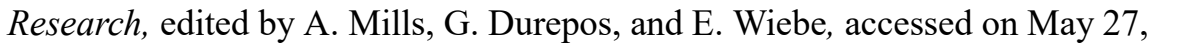

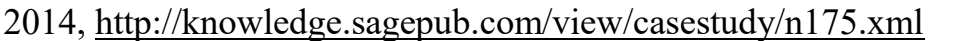

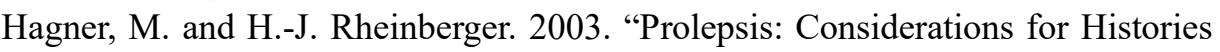
पWIScience after 2000.” In Social Studies of Science and Technology:

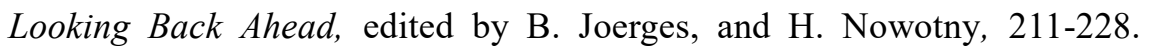

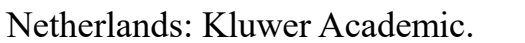

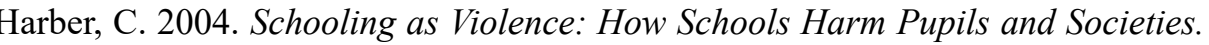

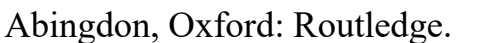

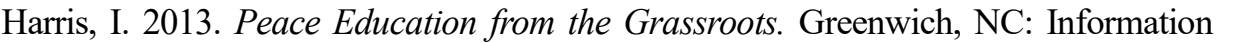

$\square \square\|\square\| \square \| \square$

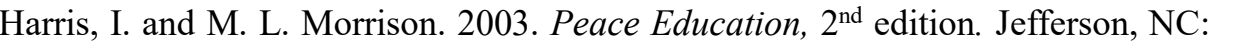

$\square \quad \square \quad \square \square\|\| \| \square$

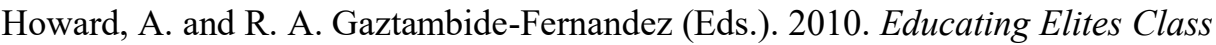

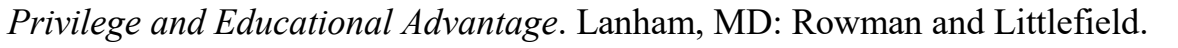

Jansen, H. 2010. "The Logic of Qualitative Survey Research and its Posit $\square \square \square \square \square$

Field of Social Research Methods." Forum Qualitative Sozialforschung/

Forum: Qualitative Social Research

$\square \square\|\|\|\|\|\square\| \|$ A. 2006. "Concepts of Teacher Knowledge as Social Strategies."

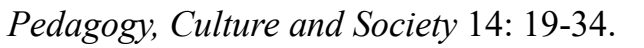

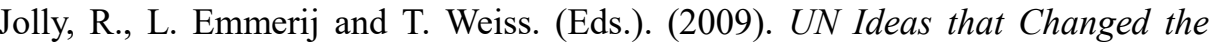

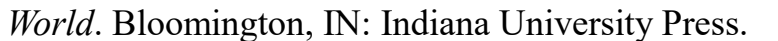

Kester, K. 2016. "The Case of Educational Peacebuilding Inside the United

Nations Universities: A Review and Critique." Journal of Transformative

Education

Kester, K. 2017a. "The United Nations, Peace and Higher Education: Pedagogic Interventions in Neoliberal Times." Review of Education, Pedagogy and Cultural Studies.

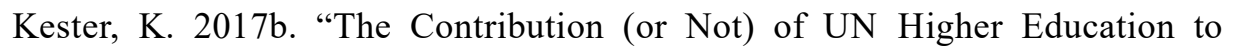

Peacebuilding: An Ethnographic Account." Globalisation, Societies and

Education.

Kester, K and Cremin, H. 2017. "Peace Education and Peace Education Research:

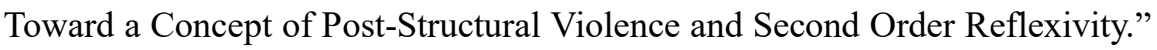

Educational Philosophy and Theory $\square \square \square\|\Pi\| \backslash \square$

$\square \square\|\|\|\|\|\|\|\| \|$ The Parliament of Man. The Past, Present and Future of the

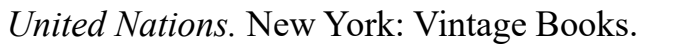

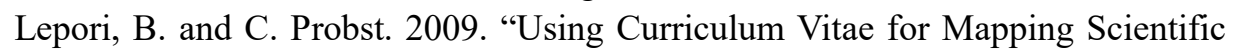


\begin{tabular}{ll|l|l|l|l|} 
&
\end{tabular}

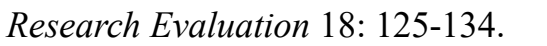

$\square \square\|\square \square\| \|$ Preventing Violent Conflicts.

MacGinty, R. 2012. "Routine Peace: Technocracy and Peacebuilding." Cooperation and Conflict

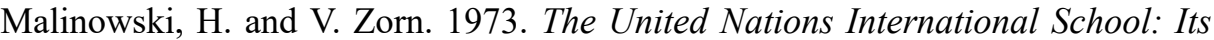

History and Development.

Martin, N. 2008. "Activities Report: United Nations mandated University for

Peace Alumni Advocacy Project.” Journal of Peace Education $\square \square \| \mid ण$

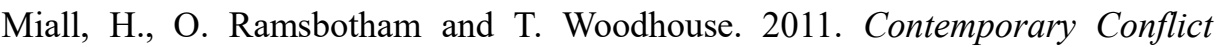

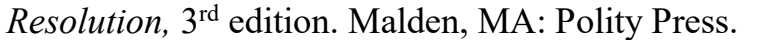

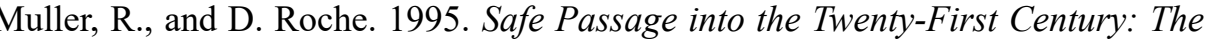

United Nations' Quest for Peace, Equality, Justice and Development. $\square \square \square \square$

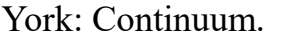

Mundy, K. 1998. "Educational Multilateralism and World (Dis)Order.” Comparative

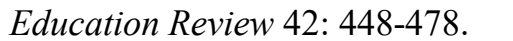

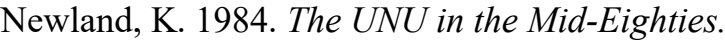

O’Rourke, B., J. Hogan, and P. Donnelly. 2015. "Developing an Elite Formation

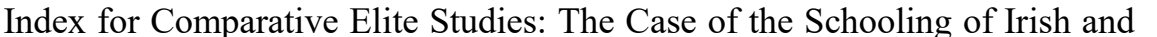

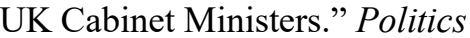

Page, J. 2008. "The United Nations and Peace Education." In Encyclopedia of

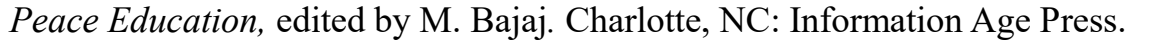

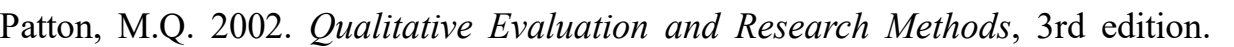

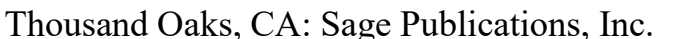

Posecznick, A. 2013. "Constructing Legitimacy in a Non $\square \square\|\|\|\|\|\square \square \square\| \square \square$ College: Unpacking Symbolic Capital through Ethnographic Moments."

Ethnography and Education $\square: \square \square \square \square$

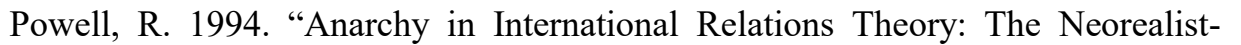

Neoliberal Debate." International Organization $\square \square\|\|\|\|\|\| \|$

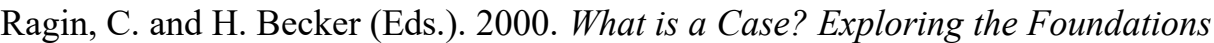

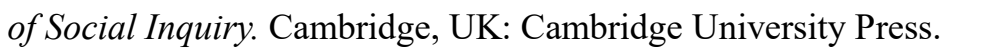

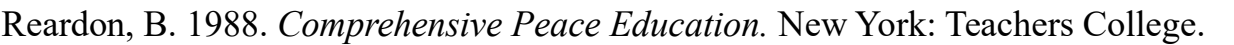

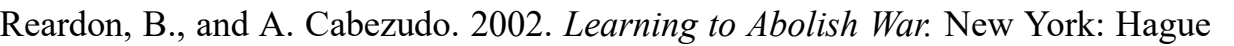

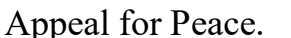

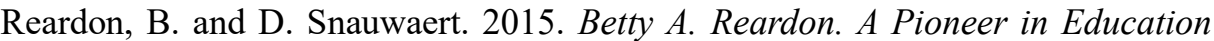

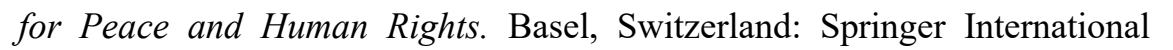

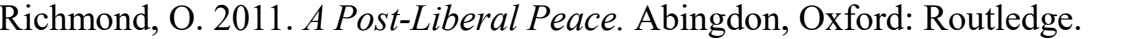

Routley, L. 2016. “Teaching Africa, Presenting, Representing, and the Importance

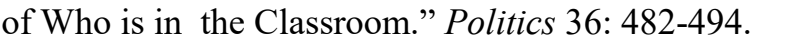

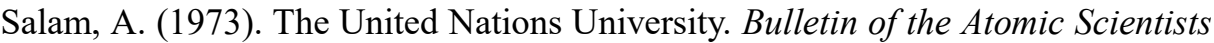




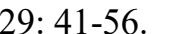

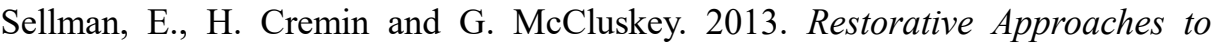
Conflict in Schools: Interdisciplinary Perspectives on Whole School Approaches

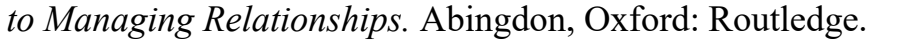

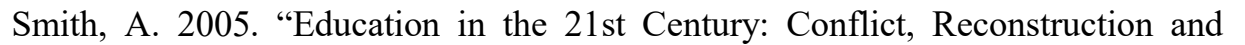
Reconciliation." Compare

Smith, S. 2000. "The Discipline of International Relations: Still an $\square \square \square\|\| \| \square$ Social Science?" British Journal of Politics and International Relations $\square \square$ $\square \square|\Pi|||||$

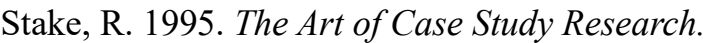

Takayama, K., A. Sriprakash and R. W. Connell. 2017. "Toward a Postcolonial

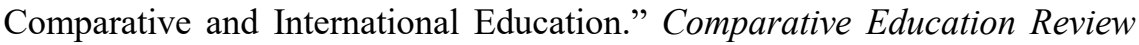

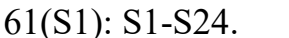

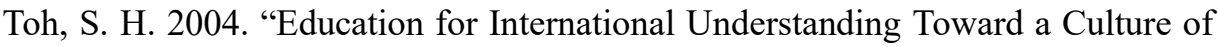
Peace: A Conceptual Framework." In Education for International Understanding $\square$ Toward a Culture of Peace: Teachers Resource Book, $\square\|\|\|\square \square \square\| \square \square \square$,

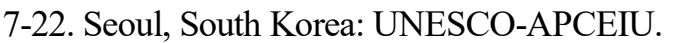

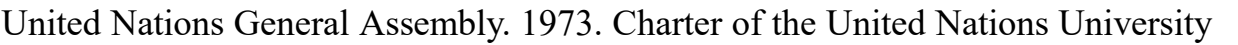

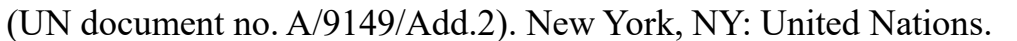

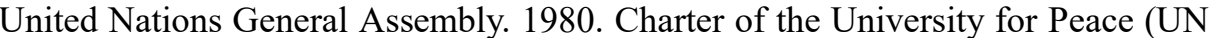

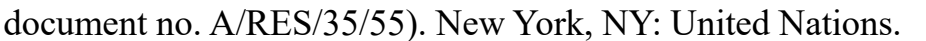

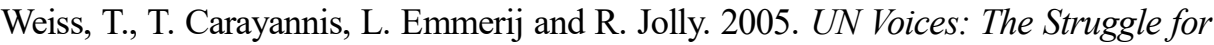

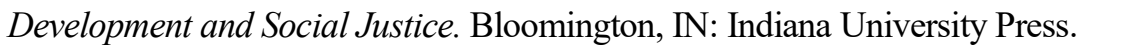

White, J., S. Drew, and T. Hay. 2009. "Ethnography Versus Case Study.” Qualitative Research Journal $\square\|\|\|\| \square$

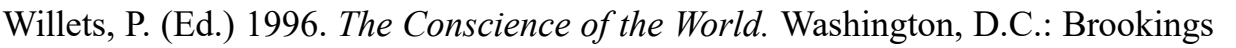

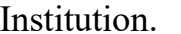

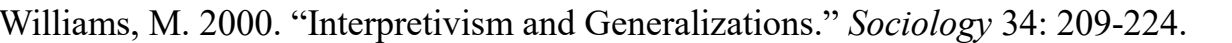

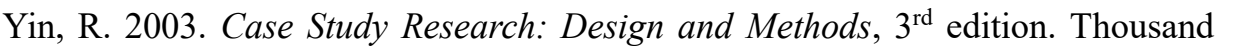

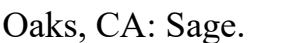

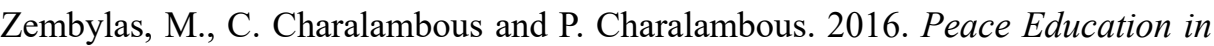
a Conflict-Affected Society: An Ethnographic Journey. $\quad \square \square \square \square \| ा ण \square \square \square$

Zucker, D. 2009. "How To Do Case Study Research." In Teaching Research

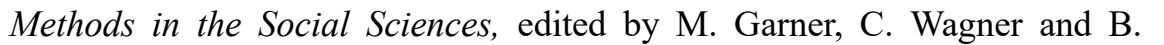

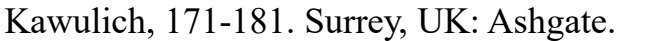




\section{ENDNOTES}

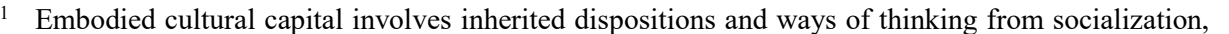

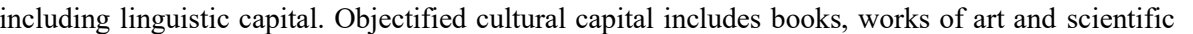

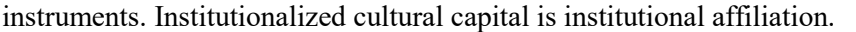

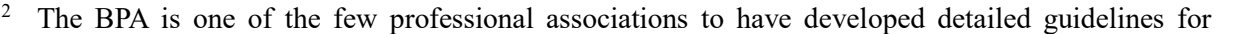

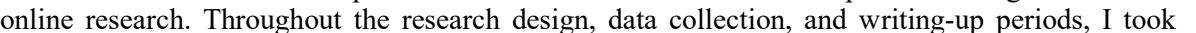

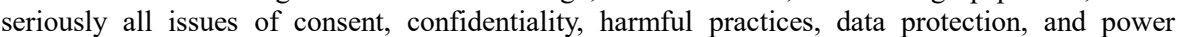

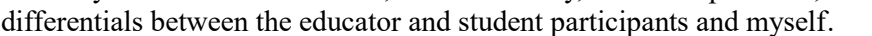

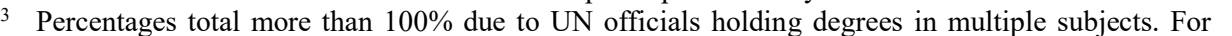
example, a single official may hold an undergraduate degree in sociology, a Master's degree in

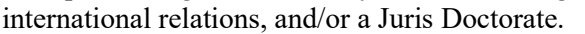

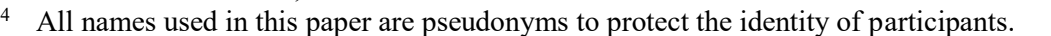

